\title{
Improvements in the profiles and distributions of nitric acid and nitrogen dioxide with the LIMS version 6 dataset
}

\author{
E. Remsberg ${ }^{1}$, M. Natarajan ${ }^{1}$, B. T. Marshall ${ }^{2}$, L. L. Gordley ${ }^{2}$, R. E. Thompson ${ }^{2}$, and G. Lingenfelser ${ }^{3}$ \\ ${ }^{1}$ NASA Langley Research Center, 21 Langley Blvd., Mail Stop 401B, Hampton, VA 23681 USA \\ ${ }^{2}$ GATS Incorporated, 11864 Canon Blvd., Suite 101, Newport News, VA 23606 USA \\ ${ }^{3}$ SSAI, 1 Enterprise Parkway, Hampton, VA 23661 USA
}

Received: 14 December 2009 - Published in Atmos. Chem. Phys. Discuss.: 3 February 2010

Revised: 11 May 2010 - Accepted: 13 May 2010 - Published: 26 May 2010

\begin{abstract}
The quality of the Nimbus 7 Limb Infrared Monitor of the Stratosphere (LIMS) nitric acid $\left(\mathrm{HNO}_{3}\right)$ and nitrogen dioxide $\left(\mathrm{NO}_{2}\right)$ profiles and distributions of 1978/1979 are described after their processing with an updated, Version 6 (V6) algorithm and subsequent archival in 2002. Estimates of the precision and accuracy of both of those species are developed and provided herein. The character of the V6 $\mathrm{HNO}_{3}$ profiles is relatively unchanged from that of the earlier LIMS Version 5 (V5) profiles, except in the upper stratosphere where the interfering effects of $\mathrm{CO}_{2}$ are accounted for better with V6. The accuracy of the retrieved V6 $\mathrm{NO}_{2}$ is also significantly better in the middle and upper stratosphere, due to improvements in its spectral line parameters and in the reduced biases for the accompanying V6 temperature and water vapor profiles. As a result of these important updates, there is better agreement with theoretical calculations for profiles of the $\mathrm{HNO}_{3} / \mathrm{NO}_{2}$ ratio, day-to-night $\mathrm{NO}_{2}$ ratio, and with estimates of the production of $\mathrm{NO}_{2}$ in the mesosphere and its descent to the upper stratosphere during polar night. In particular, the findings for middle and upper stratospheric $\mathrm{NO}_{2}$ should also be more compatible with those obtained from more recent satellite sensors because the effects of the spin-splitting of the $\mathrm{NO}_{2}$ lines are accounted for now with the LIMS V6 algorithm. The improved precisions and more frequent retrievals of the LIMS profiles along their orbit tracks provide for better continuity and detail in map analyses of these two species on pressure surfaces. It is judged that the chemical effects of the oxides of nitrogen on ozone can be studied quantitatively throughout the stratosphere with the LIMS V6 data.
\end{abstract}

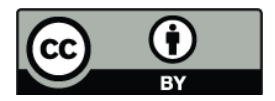

Correspondence to: E. Remsberg (ellis.e.remsberg@nasa.gov)

\section{Background}

The Limb Infrared Monitor of the Stratosphere (LIMS) experiment was launched on 24 October 1978 on the near polarorbiting Nimbus 7 satellite. LIMS operated from 25 October until 28 May 1979, measuring vertical radiance profiles across the atmospheric limb of the Earth (Gille and Russell, 1984). Single limb radiance profiles were measured about every 12 seconds along an orbital track of the LIMS tangent point locations. Its daily orbital data extend from $64^{\circ} \mathrm{S}$ to $84^{\circ} \mathrm{N}$ and are available at two local times per latitude (at about $1300 \mathrm{~h}$ and $2300 \mathrm{~h}$ at the Equator). The radiances were processed to infer middle atmospheric temperature profiles and the concentrations of several chemical compounds important for the chemistry of stratospheric ozone. LIMS provided profiles of ozone $\left(\mathrm{O}_{3}\right)$, water vapor $\left(\mathrm{H}_{2} \mathrm{O}\right)$, nitric acid $\left(\mathrm{HNO}_{3}\right)$, and nitrogen dioxide $\left(\mathrm{NO}_{2}\right)$. Thus, LIMS was the first satellite experiment to provide a simultaneous, near-global view of the key chemical compounds in the ozone/nitrogen oxide photochemical chain. The temperature, geopotential height, and constituent profiles have been used for many scientific investigations, including effects of radiation on the net transport (Mlynczak et al., 1999), responses of the middle atmosphere to perturbations (Leovy et al., 1985), and correlations between the temperature and species data (Froidevaux et al., 1989).

The LIMS Version 5 (or V5) profile dataset was archived in 1982; its measurements, algorithms, and data products are described in Gille and Russell (1984) and references therein. Since that time, significant improvements have been realized in the original spectroscopic parameters (Drayson et al., 1984) that were used for the V5 retrieval of temperature/pressure or $\mathrm{T}(\mathrm{p})$ and for the gaseous constituent profiles

Published by Copernicus Publications on behalf of the European Geosciences Union. 
Table 1. Calculations of precision and accuracy (\%) for LIMS V6 $\mathrm{HNO}_{3}$.

\begin{tabular}{llllll}
\hline Pressure (hPa) & 80 & 50 & 30 & 10 & 3 \\
\hline Random (PRECISION) & 21 & 4 & 3 & 3 & 10 \\
Calibration & 1 & 1 & 2 & 1 & 7 \\
Temperature Bias & 5 & 1 & 3 & 1 & 6 \\
Spectral Band Model Error & 5 & 5 & 5 & 5 & 5 \\
CFC \& Aerosol Corrections & 5 & 5 & 2 & 1 & 1 \\
Registration \& Forward Model Errors & 13 & 6 & 5 & 5 & 5 \\
Root-Sum-Squares (RSS) of bias errors (ACCURACY) & 16 & 9 & 8 & 7 & 12 \\
Unverified Sources of Error & & & & & \\
FOV Side Lobes & 27 & 28 & 25 & 27 & 45 \\
Out-of-band Spectral Signal & 29 & 29 & 20 & 7 & 45 \\
\hline
\end{tabular}

that contribute to the radiances measured within the six channels of LIMS. For this reason a reprocessing of the LIMS Level 2 (or profile) data to Version 6 (V6) was considered for several of its primary and interfering gases using the line parameters of HITRAN 92 (Rothman et al., 1992a). As a result, these V6 data are considered more appropriate for comparisons with the temperature and species distributions obtained from the several middle atmosphere instruments onboard the NASA Upper Atmosphere Research Satellite (UARS), the Earth Observing System (EOS) Aura satellite and on the Canadian, European, and/or Japanese satellites SCISAT, ODIN, ENVISAT, and ADEOS.

The V6 dataset contains improvements due to a better knowledge of the orbital attitude for the LIMS measurements, from the application of a multiple interleave retrieval process, and from using all the radiance profile samples, spaced $0.375 \mathrm{~km}$ in altitude. Descriptions of the V6 algorithms for the conditioned radiances of all the channels and for the retrieval of the temperature and geopotential height profiles are in Remsberg et al. (2004). Characterizations of the improvements for V6 ozone and water vapor are provided in Remsberg et al. (2007, 2009). This paper is focused on the improvements and scientific implications for the $\mathrm{V} 6 \mathrm{HNO}_{3}$ and $\mathrm{NO}_{2}$ profiles and distributions.

The LIMS instrument is essentially a limb-viewing radiometer, and the optical characteristics of all the channels are given in Russell and Gille (1978, their Table 1). A single LIMS scan profile begins with the center of its field-of-view (FOV) array viewing the horizon at $153 \mathrm{~km}$ altitude, moving steadily downward to a point $38 \mathrm{~km}$ below the solid Earth limb and then returning upward in the same manner. The angular resolutions (in milliradians or mrad) for the detectors of the FOV array are $1 \mathrm{mrad}$ for the $\mathrm{NO}_{2}$ and $\mathrm{H}_{2} \mathrm{O}$ channels and $0.5 \mathrm{mrad}$ for the other four LIMS channels, including $\mathrm{HNO}_{3}$. Their instantaneous FOV at the horizon is $3.6 \mathrm{~km}$ for $\mathrm{NO}_{2}$ and $\mathrm{H}_{2} \mathrm{O}$ and $1.8 \mathrm{~km}$ for $\mathrm{HNO}_{3}, \mathrm{O}_{3}$, and for temperature from its two $\mathrm{CO}_{2}$ channels. Radiance samples are obtained every $0.375 \mathrm{~km}$ in altitude for $\mathrm{HNO}_{3}$ and $0.75 \mathrm{~km}$ for
$\mathrm{NO}_{2}$. The filter for the LIMS $\mathrm{HNO}_{3}$ channel extends from 842 to $915 \mathrm{~cm}^{-1}$, its $5 \%$ transmission points. That channel measured the radiance emitted by the $v_{5}$ and $2 v_{9}$ bands or in the region of $11.3 \mu \mathrm{m}$. The $\mathrm{V} \mathrm{HNO}_{3}$ retrievals were obtained using the same laboratory-measured, band parameters used to process the LIMS V5 profiles (Drayson et al., 1984; Goldman et al., 1981). Thus, the primary improvements for V6 $\mathrm{HNO}_{3}$ occur in the upper stratosphere due to accounting for the $\mathrm{CO}_{2}$ laser band emission centered near $10.4 \mu \mathrm{m}$ and in the lower stratosphere from the underlying emissions of the CFCs and aerosols. The filter for the LIMS $\mathrm{NO}_{2}$ channel has its $5 \%$ transmission points at 1561 and $1631 \mathrm{~cm}^{-1}$. The effects of the spin splitting for its lines are included in the line parameters of HITRAN 92 that we used (Rothman et al., 1992a). The band intensity for the primary $\mathrm{NO}_{2} v_{3}$ cold band of HITRAN 92 was also unchanged for HITRAN 96 (Rothman et al., 1998), although the strengths of its assigned lines are altered somewhat in HITRAN 96 based on the analyses of Toth (1992).

The LIMS retrievals make use of an onion-peeling approach along with the emissivity growth approximation (EGA) of Gordley and Russell (1981). The V6 Level 2 data files contain both the de-convolved radiances and the retrieved parameters, and they are tabulated at 18 levels per decade of pressure or at a spacing of about $0.88 \mathrm{~km}$. Note that the UARS Level 3A profiles have 6 levels of data per decade of pressure and represent a matching subset to the LIMS V6 data for easy comparison. In addition, the time, location, and solar zenith angle for the tangent point of a LIMS measurement are included in the header lines of each profile. This information makes it easier to relate the LIMS profiles of $\mathrm{O}_{3}, \mathrm{HNO}_{3}$, and $\mathrm{NO}_{2}$ to photochemical model output. The effective vertical resolution for both $\mathrm{V}_{6} \mathrm{HNO}_{3}$ and $\mathrm{NO}_{2}$ is of order $3.7 \mathrm{~km}$, and retrievals were performed for each of the down/up scan pairs spaced about 1.6 degrees of latitude along the LIMS orbital tangent tracks. Distributions of $\mathrm{HNO}_{3}$ extend from near the tropopause to just above the 2-hPa level. The nighttime distributions of $\mathrm{NO}_{2}$ extend from 
about $50 \mathrm{hPa}$ to the lower mesosphere, especially for the polar night. Results for daytime $\mathrm{NO}_{2}$ are useful from about $50 \mathrm{hPa}$ to $1 \mathrm{hPa}$.

Section 2 shows several daily, zonally-averaged distributions of the $\mathrm{V}_{6} \mathrm{HNO}_{3}$ and $\mathrm{NO}_{2}$ for comparisons with model output and with distributions from more recent satellite experiments that also were observing during periods when the stratospheric aerosol loading was near background levels. An extensive validation of the V6 products was not conducted, although their daily zonal mean cross sections have been assessed against those of the V5 data that had been compared with the few correlative measurements available during the LIMS timeframe (e.g., Gille et al., 1984; Gille, 1987; Russell et al., 1984a; Remsberg and Russell, 1987). Qualitative improvements have been found for all the V6 data products.

Section 3 describes the significant changes in the V6 algorithm that affect the V6 $\mathrm{HNO}_{3}$ and $\mathrm{NO}_{2}$ profiles. Precision and accuracy for those V6 data are included, based on calculations of the effects of their known error sources. These calculated precisions are shown to compare well with the variations in the retrieved $\mathrm{HNO}_{3}$ and $\mathrm{NO}_{2}$ from among adjacent scans along an orbit, specifically for latitudes and times when zonal variations due to wave activity were minimal. Section 4 presents some scientific findings demonstrating the improved quality of the $\mathrm{V} 6 \mathrm{HNO}_{3}$ and $\mathrm{NO}_{2}$. Section 5 is a summary of findings about the changes with V6.

\section{Zonally-averaged distributions of $\mathrm{HNO}_{3}$ and $\mathrm{NO}_{2}$}

There were 13 to 14 orbits of data per day from LIMS, following the Sun-synchronous geometry for the Nimbus 7 satellite (Gille and Russell, 1984). Retrievals were performed on the radiance profiles, located along the ascending (south-to-north) and the descending (north-to-south) node, tangent tracks of each orbit. The local time of a measurement at the low and middle latitudes is near 1 p.m. for the ascending node and $11 \mathrm{p} . \mathrm{m}$. for the descending node data. As an introduction, we show several $\mathrm{V}_{6} \mathrm{HNO}_{3}$ and $\mathrm{NO}_{2}$ distributions obtained from the LIMS Level 2 profiles.

Figure 1 provides the daily, zonally-averaged distributions of $\mathrm{V} 6 \mathrm{HNO}_{3}$ from the combination of its species profiles from the descending and ascending orbital segments for 15 November 1978, (top panel) and 16 May 1979 (bottom panel). Maximum mixing ratio values occur at the high latitudes near $30 \mathrm{hPa}$, and the variation of $\mathrm{HNO}_{3}$ with latitude is similar to that from the earlier V5 dataset at that pressure level (Gille et al., 1984, 1993). However, the V6 $\mathrm{HNO}_{3}$ profiles no longer show nearly constant values in the upper stratosphere, as was the case for V5 in Jackman et al. (1985). This improvement is due primarily to a better accounting for the effects of the interfering radiance from the laser band of carbon dioxide $\left(\mathrm{CO}_{2}\right)$ at $10.4 \mu \mathrm{m}$. The V6 $\mathrm{HNO}_{3}$ agrees reasonably well with the photochemical model estimates of Jackman et al. (1985). The LIMS V6 daytime values are
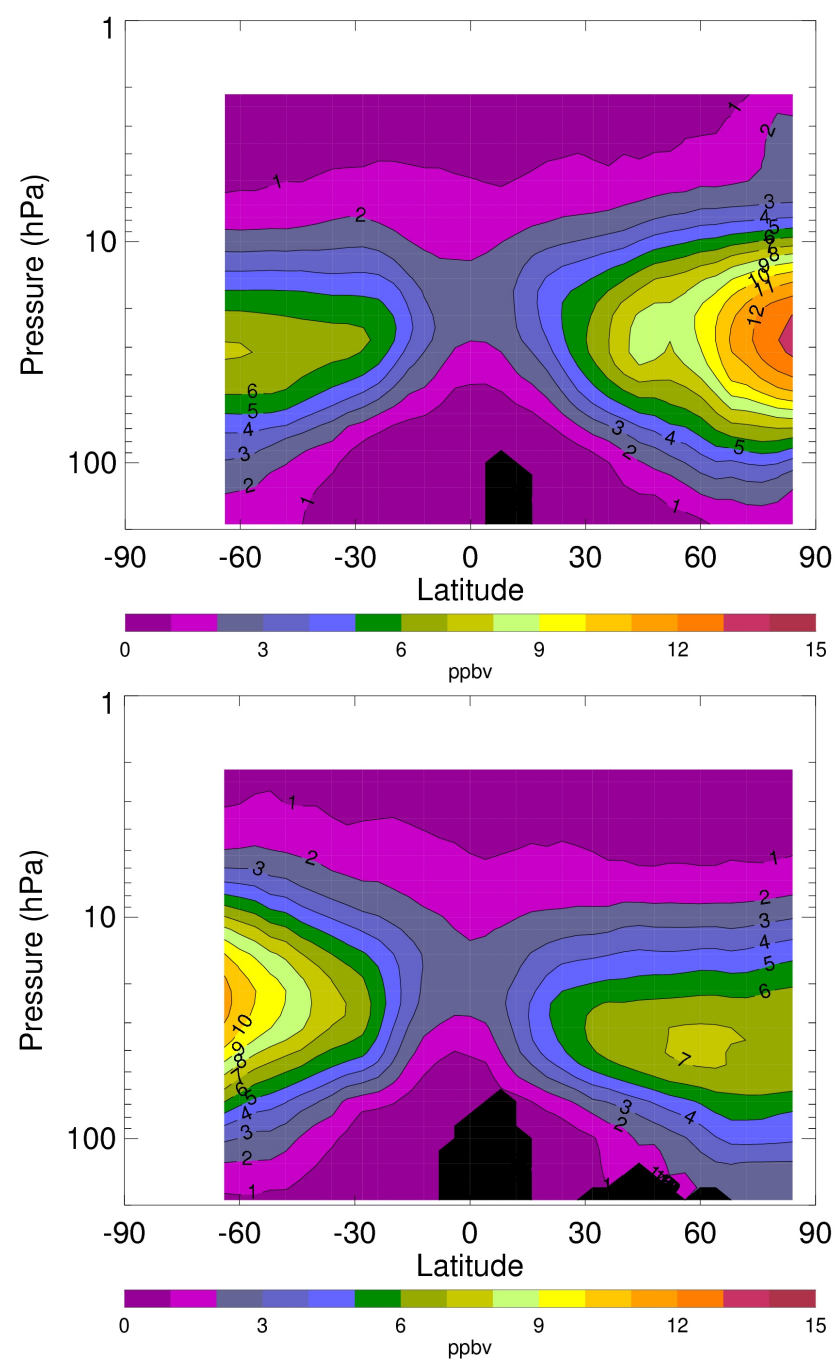

Fig. 1. V6 $\mathrm{HNO}_{3}$ distributions in ppbv for (top) 15 November 1978 and (bottom) 16 May 1979, based on a combination of the profile data from their ascending and descending orbital segments. Orangeto-red colors represent high values and magenta colors are low values; blackened regions indicate where there are no data.

slightly less than its nighttime values near the 4-hPa level (not shown), possibly due to not having accounted accurately for the effects of the temperature tides on the LIMS $\mathrm{HNO}_{3}$ radiances. $\mathrm{V}_{6} \mathrm{HNO}_{3}$ values are somewhat smaller than those of V5 in the tropical lower stratosphere, due to first-order corrections in the V6 algorithm for the effects of interfering emissions from aerosols and from the chlorofluorocarbon (CFC) molecules $\mathrm{CFCl}_{3}$ and $\mathrm{CF}_{2} \mathrm{Cl}_{2}$. The $1 \mathrm{ppbv}$ contour extends to just above the $50-\mathrm{hPa}$ level at equatorial latitudes; that value is at the upper limit of reactive nitrogen $\left(\mathrm{NO}_{\mathrm{y}}\right)$ minus odd nitrogen $\left(\mathrm{NO}_{\mathrm{x}}\right)$ from in situ measurements (e.g., Jensen and Drdla, 2002, and references therein).

One can see from Fig. 1 that there is very good seasonal symmetry between the $\mathrm{HNO}_{3}$ distributions of the middle and 

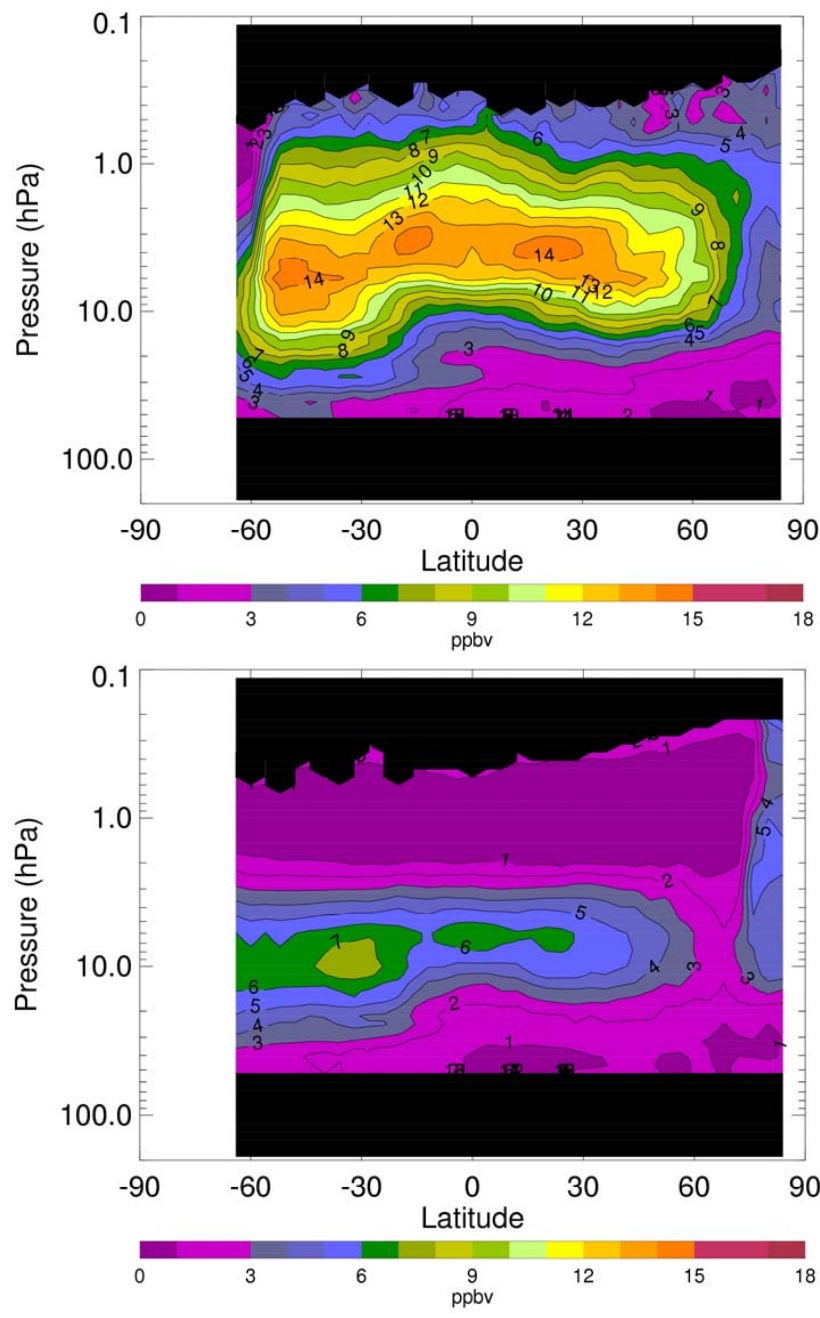

Fig. 2. LIMS V6 distributions for 15 November 1978 of (top) descending (or nighttime) $\mathrm{NO}_{2}$ and of (bottom) ascending (or daytime) $\mathrm{NO}_{2}$ both in ppbv. Orange colors are high values, while magenta-to-purple colors are low values; blackened regions indicate where there are no data. There is a crossover to polar night conditions at about $75^{\circ} \mathrm{N}$ for the ascending $\mathrm{NO}_{2}$.

lower stratosphere for November versus May of the northern and southern hemispheres. Austin et al. (1986) explained that the increases in fall and winter were likely a result of heterogeneous, chemical production mechanisms. Note that the values of $\mathrm{HNO}_{3}$ are also larger in November at high northern latitudes of the upper stratosphere (top panel of Fig. 1). This feature becomes even more prominent in midwinter due to an accumulation of $\mathrm{HNO}_{3}$ from a chemical conversion of $\mathrm{NO}_{2}$ and di-nitrogen pentoxide $\left(\mathrm{N}_{2} \mathrm{O}_{5}\right)$ under polar night conditions (e.g., Kawa et al., 1995; Bekki et al., 1997; Stiller et al., 2005). The distribution of 16 May (bottom panel of Fig. 1) also indicates that there was an accumulation of $\mathrm{HNO}_{3}$ in the lower part of the northern, polar stratosphere from the winter and early spring.
Because $\mathrm{NO}_{2}$ undergoes large diurnal variations in the upper stratosphere, Fig. 2 shows its zonal-averages from the descending (or local nighttime at low and middle latitudes top panel) and from the ascending (or local daytime at low and middle latitudes - bottom panel) orbital segments for 15 November 1978. Maximum mixing ratio values for the nighttime LIMS $\mathrm{NO}_{2}$ of Fig. 2 (top panel) are of the order of $14 \mathrm{ppbv}$ centered at about the $4-\mathrm{hPa}$ level. The retrieved nighttime $\mathrm{NO}_{2}$ profiles extend into the lower mesosphere, where they encounter their signal-to-noise $(\mathrm{S} / \mathrm{N})$ limit and are less accurate. The repartitioning of the $\mathrm{NO}_{\mathrm{x}}$ (nitric oxide (NO) $+\mathrm{NO}_{2}$ ) at twilight occurs at about 55 to $60^{\circ} \mathrm{S}$ latitude. Those terminator $\mathrm{NO}_{2}$ profiles are also less accurate because their rapidly changing $\mathrm{NO}_{2}$ values along the tangent path were not accounted for in the same manner as in Solomon et al. (1986).

Maximum mixing ratios for the ascending $\mathrm{NO}_{2}$ (daytime at most latitudes) of Fig. 2 (bottom panel) are of the order of 6 to $7 \mathrm{ppbv}$ and occur between 8 and $10 \mathrm{hPa}$. Note that there is a crossover to polar night conditions at about $75^{\circ} \mathrm{N}$. The daytime $\mathrm{NO}_{2}$ at the lower latitudes is small in the upper stratosphere because most of the $\mathrm{NO}_{\mathrm{x}}$ is in the form of NO. $\mathrm{H}_{2} \mathrm{O}$ emission becomes a significant part of the $\mathrm{NO}_{2}$ channel radiance in the upper stratosphere, especially during daytime. The forward radiance model for the $\mathrm{V} 6 \mathrm{NO}_{2}$ channel assumes that $\mathrm{H}_{2} \mathrm{O}$ has a constant value of $6.5 \mathrm{ppmv}$ above the upper limit of $1.3 \mathrm{hPa}$ for its V6 profile. Furthermore, there is a significant amount of extra emission in the mesosphere during daylight from excited states of the $\mathrm{H}_{2} \mathrm{O}$ molecule that are difficult to characterize for LIMS, primarily because its ground-state $\mathrm{H}_{2} \mathrm{O}$ populations are not known exactly for those altitudes (Lopez-Puertas and Taylor, 2001; Kerridge and Remsberg, 1989). For this reason no corrections for non-LTE effects from $\mathrm{H}_{2} \mathrm{O}$ were developed for the retrieval of the $\mathrm{V} 6 \mathrm{NO}_{2}$. That source of positive radiance bias is the most likely reason for the spurious, upward extension of the daytime $\mathrm{NO}_{2}$ distributions above the 1-hPa level from $64^{\circ} \mathrm{S}$ to $\sim 70^{\circ} \mathrm{N}$ (see also Sects. 3 and 4 ).

Figure 3 is the distribution of $\mathrm{NO}_{2}$ from the descending (nighttime) orbital segments of 15 January 1979, and it is similar to that of Fig. 2 (top panel) in most respects. One exception is the occurrence of larger values of $\mathrm{NO}_{2}$ in the upper stratosphere near $50^{\circ} \mathrm{S}$ in Fig. 3 than in Fig. 2. This difference is partly a diurnal effect. The LIMS $\mathrm{NO}_{2}$ measurements for the descending orbital segments were obtained at about $2130 \mathrm{~h}$ (local time) at $50^{\circ} \mathrm{S}$ versus $2300 \mathrm{~h}$ at the equator, and there is a steady conversion of $\mathrm{NO}_{2}$ to $\mathrm{N}_{2} \mathrm{O}_{5}$ from just after sunset and until sunrise. Furthermore, sunset occurs later in the day during summer at the high southern latitudes.

The elevated values of $\mathrm{NO}_{2}$ in the mesosphere at the high latitudes of the northern hemisphere are another feature of Fig. 3. Such enhanced values of $\mathrm{NO}_{2}$ were first reported by Russell et al. (1984b) based on a special, radiance-averaged version of the LIMS data, and they were attributed to the formation of $\mathrm{NO}_{\mathrm{x}}$ in the mesosphere followed by a gradual 
descent of the air to the uppermost stratosphere during polar night. Findings from more recent satellite sensors support that interpretation (e.g., Randall et al., 2009). A time series of the V6 polar night $\mathrm{NO}_{2}$ will be shown in Sect. 4, indicating the improved estimates for its values and a better continuity for its descent during the winter months of 1978/1979.

\section{LIMS V6 retrieval algorithms and error estimates}

\subsection{The V6 algorithms for $\mathrm{HNO}_{3}$ and $\mathrm{NO}_{2}$}

Emissivity data tables for the forward limb-radiance algorithms were developed as a function of temperature and pressure for each of the gases that make contributions in the $\mathrm{HNO}_{3}$ and $\mathrm{NO}_{2}$ channels. The V6 forward model for $\mathrm{HNO}_{3}$ makes use of the cross section parameters of Goldman et al. (1981), based on the laboratory measurements of Giver et al. (1984). That parameterization is appropriate for the broadband $\mathrm{HNO}_{3}$ channel of LIMS, and it is essentially unchanged from that used for V5. Although there were uncertainties associated with the line parameters on the HITRAN $\mathrm{HNO}_{3}$ databases during the 1990s, it is noted that the $\mathrm{HNO}_{3}$ line intensities in the 11- $\mu$ m region for HITRAN 96 also include normalizations to the band intensities of Giver et al. (1984).

The $\mathrm{HNO}_{3}$ channel contains secondary radiance contributions from the laser band of $\mathrm{CO}_{2}$ at 10.4 micrometers and from the primary $\mathrm{CFCs}\left(\mathrm{CFCl}_{3}\right.$ and $\left.\mathrm{CF}_{2} \mathrm{Cl}_{2}\right)$. The line parameters for $\mathrm{CO}_{2}$ were taken from HITRAN 92 (Rothman et al., 1992a and b; Dana et al., 1992), which are improved over the parameters used with the original LIMS V5 algorithm. To achieve better accuracy for the emissivity of $\mathrm{CO}_{2}$ along a tangent ray path, its emissivity table values were generated at 55 pressure levels and 33 temperature levels encompassing their expected atmospheric ranges. In addition, polynomial fits were not used to account for the temperature dependence within the emissivity tables; linear interpolation was employed instead. These upgrades have led to a more accurate representation of the effects of the laser band of $\mathrm{CO}_{2}$. To summarize, the V6 emissivity tables for $\mathrm{CO}_{2}$ account for much of the excess of retrieved $\mathrm{HNO}_{3}$ that characterized the V5 $\mathrm{HNO}_{3}$ profiles from about 5 to $2 \mathrm{hPa}$, as originally reported in Gille et al. (1984), Jackman et al. (1985), and Gille et al. (1993) (see also Sect. 4).

Line parameters for the original V5 retrievals of $\mathrm{NO}_{2}$ were obtained from the AFGL trace gas compilation (Rothman et al., 1981). Later, the spin-rotation effects of $\mathrm{NO}_{2}$ were identified, and the fine structure of the lines for the primary $v_{3}$ cold band was included in the HITRAN 92 compilation via a perturbation calculation (Perrin et al., 1992). This update accounts for most of the improvements in the $\mathrm{V}^{6} \mathrm{NO}_{2}$ profiles (Remsberg et al., 1994). Only minor changes in the retrieved $\mathrm{NO}_{2}$ are expected from the more explicit calculations of the strengths of those resolved lines reported by Toth (1992)

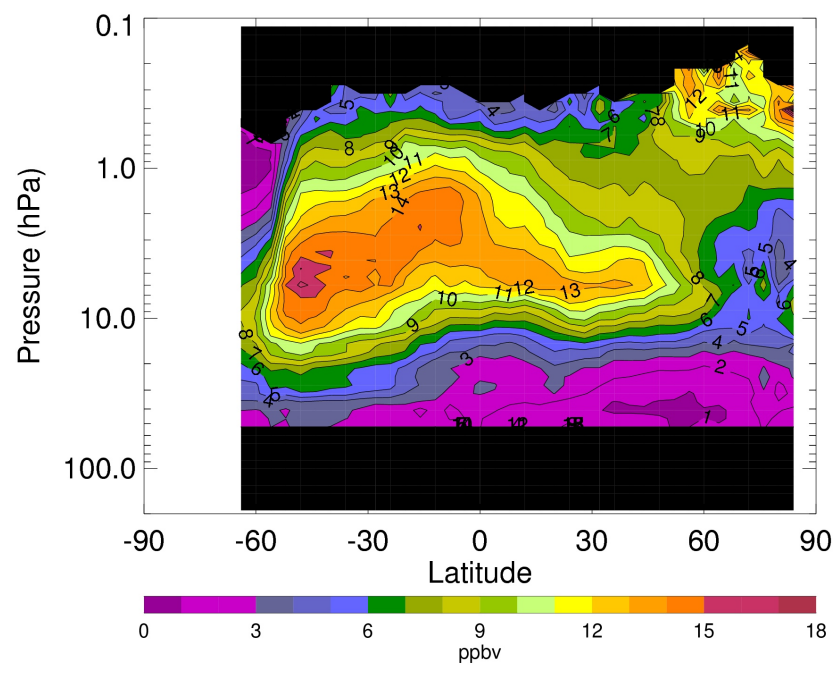

Fig. 3. As in the top panel of Fig. 2, but for descending (or nighttime) $\mathrm{NO}_{2}$ in ppbv for 15 January 1979. Orange-to-red colors are high values and magenta-to-purple colors are low values; blackened regions are where there are no data.

and available later in HITRAN 96. The LIMS $\mathrm{NO}_{2}$ channel also contains contributions from $\mathrm{H}_{2} \mathrm{O}, \mathrm{CH}_{4}$, and the oxygen $\left(\mathrm{O}_{2}\right)$ continuum, and tables were developed for each of them. Since the LIMS $\mathrm{NO}_{2}$ radiances are interfered with substantially by $\mathrm{H}_{2} \mathrm{O}$ in the stratosphere, an additional emissivity table was employed to account for the effects of their overlapping lines (Remsberg et al., 2004). Spectral parameters for the underlying $\mathrm{O}_{2}$ were not available, so the empirical model of Thibault et al. (1997) was used for consistent calculations of the effects of the continuum-induced $\mathrm{O}_{2}$ absorption in both the LIMS $\mathrm{H}_{2} \mathrm{O}$ and $\mathrm{NO}_{2}$ channels.

The LIMS V6 profiles were used to correct for the forward radiance contributions of $\mathrm{H}_{2} \mathrm{O}$ in the $\mathrm{NO}_{2}$ channel up to about the 1.5-hPa level, and then they were extended upward using a constant value of 6.5 ppmv. In addition, the entire $\mathrm{H}_{2} \mathrm{O}$ profile for the forward model was smoothed by a Gaussian function having a half-width of $1.5 \mathrm{~km}$ at half maximum. As indicated earlier, no corrections were developed to account for non-LTE radiances from mesospheric $\mathrm{H}_{2} \mathrm{O}$ during daytime. Even so, there is no indication of a bias in the retrieved $\mathrm{NO}_{2}$ due to that neglect, except at and above about $48 \mathrm{~km}$ (near $1 \mathrm{hPa}$ ). Emissions from excited states of daytime $\mathrm{NO}_{2}$ were postulated for the upper stratosphere by Kerridge and Remsberg (1989), but no corrections for those effects were developed for V6 because the populations of those states were not known well. More importantly, Funke et al. (2005a) reported finding no evidence for such non-LTE effects in upper stratospheric $\mathrm{NO}_{2}$ from the higher spectralresolution data of MIPAS on the ENVISAT satellite. The effects of horizontal mixing ratio gradients in the tangent layer were shown to be important for the retrieval of LIMS $\mathrm{NO}_{2}$ in the region of the day/night terminator (Solomon et al., 1986). 
However, because such a gradient correction is needed only for solar zenith angles near 90 degrees, a second-pass processing was not applied to the $\mathrm{V} 6 \mathrm{NO}_{2}$ profiles prior to their archival in 2002.

Estimated concentrations of the interfering gases were obtained as follows. Updated, seasonal zonal-mean distributions of $\mathrm{CH}_{4}$ were generated from the UARS HALOE dataset for use with the V6 retrievals of $\mathrm{NO}_{2}$ but with an extrapolation of their magnitudes back to 1979 , based on the approximate, linear emission rate for $\mathrm{CH}_{4}$ at the ground. A similar extrapolation was performed for $\mathrm{CFCl}_{3}$ and $\mathrm{CF}_{2} \mathrm{Cl}_{2}$ for the $\mathrm{HNO}_{3}$ channel, based on their measured distributions from the UARS CLAES Version 8 dataset plus knowledge of the growth rates for their emissions since 1975. Interfering emission due to aerosols has its largest effect on the LIMS-retrieved $\mathrm{HNO}_{3}$ at low latitudes of the lower stratosphere. Zonal mean distributions of the background aerosol extinction were not available for the seven months of LIMS, and its V5 dataset had no correction for it. A first-order aerosol extinction cross section was generated for the V6 algorithm, based on estimates for the background stratospheric aerosol layer of 1978/1979. Specifically, a single zonalmean distribution of aerosol extinction was adopted, based on March/May 1996 results for the HALOE $5.26 \mu \mathrm{m}$ (nitric oxide or NO) channel (Hervig et al., 1995). The magnitude of that distribution was then scaled back to 1978/1979 using a factor obtained by comparing the SAGE II $1-\mu \mathrm{m}$ channel aerosol extinction values of 1996 versus the SAGE I aerosol extinction for the same months of 1979. That single modified, zonal mean aerosol distribution was used for each of the seven months of the LIMS dataset and must be considered as somewhat qualitative with latitude and not truly representative of its seasonal cycle variations. Since tropical aerosol extinctions vary most noticeably according to the phase of the QBO cycle (Hitchman et al., 1994), a scaling of their values between the 1996 and the 1979 March/May periods was used because they occurred at nearly the same QBO phase. Finally, aerosol extinctions at the wavelengths of the LIMS channels versus that at $5.26 \mu \mathrm{m}$ of HALOE were obtained by employing the sulfuric acid/ $\mathrm{H}_{2} \mathrm{O}$ composition and the wavelength-dependent, refractive index model for its aerosol absorption in the manner of Hervig et al. (1995).

The original V5 profiles of $\mathrm{NO}_{2}$ and $\mathrm{HNO}_{3}$ were used as a priori estimates for the $\mathrm{V} 6$ forward models, although there is no dependence upon them for the onion-peeling retrievals of LIMS once a reasonable $\mathrm{S} / \mathrm{N}$ level for the radiances was met. The archived V6 profiles were screened for anomalies using several criteria. First, the retrieval process for a tangent layer value was iterative. The variances between successive iterations were calculated, and they were checked for convergence to near the measurement noise. Those variances are defined in terms of $(\mathrm{NEN} / \mathrm{K})^{2}$, where NEN is the noise equivalent radiance for each channel in watts $/ \mathrm{m}^{2}$-sr (Gille and Russell, 1984) and $\mathrm{K}$ is the derivative of the measured signal profile as a function of the given species mixing ra- tio. Variances were set to the negative of their actual values whenever convergence was not achieved or the retrieval needed to be restarted (at tops of profiles). Valid profile segments have positive variances, and only the retrieved values from those segments were retained in the final Level 2 output file. Variance limits effectively set the extreme upper altitude of the good data for each of the parameters. Negative variances often indicate the low altitude extent of good data, too. Variance checking occurred primarily outside of the pressure ranges of $1.9 \mathrm{hPa}$ to $46 \mathrm{hPa}$ for $\mathrm{HNO}_{3}$ and of $0.88 \mathrm{hPa}$ to $46 \mathrm{hPa}$ for $\mathrm{NO}_{2}$. Independent estimates of the random error indicate that there is adequate tangent layer signal within those ranges. An additional algorithm was applied to identify and screen for contaminating radiances from cloud tops. The profiles of $\mathrm{HNO}_{3}, \mathrm{H}_{2} \mathrm{O}$, and $\mathrm{NO}_{2}$ were also screened for polar stratospheric cloud features prior to their archival, based on the occurrence of those features in the retrieved ozone profiles (Remsberg et al., 2007).

Species profile segments were also screened within given pressure ranges, when their retrieved mixing ratios exceeded certain threshold values. The pressure range for $\mathrm{HNO}_{3}$ was 2.2 to $46 \mathrm{hPa}$ and its threshold was $30 \mathrm{ppbv}$; only a very few points met that criterion, and they were judged to be spurious. $\mathrm{H}_{2} \mathrm{O}$ is a major interference for the retrieval of $\mathrm{NO}_{2}$, particularly in the polar lower stratosphere during winter; its screening threshold was set at 12 ppmv over the pressure range of 1.47 to $46 \mathrm{hPa}$. Unrealistically, large values of $\mathrm{H}_{2} \mathrm{O}$ can occur due to not resolving the temperature structure properly. $\mathrm{NO}_{2}$ thresholds were set for two separate pressure regions. Those thresholds were $25 \mathrm{ppbv}$ within 1 to $31.6 \mathrm{hPa}$ or $10 \mathrm{ppbv}$ within 36 to $68 \mathrm{hPa}$, neither of which would be explained by an excess in the retrieved $\mathrm{H}_{2} \mathrm{O}$. Almost all the profiles where $\mathrm{NO}_{2}$ exceeded $25 \mathrm{ppbv}$ in the upper stratosphere occurred in early December 1978 or in January 1979, when their temperature structures were associated with stratospheric warming events. The retrieved LIMS $\mathrm{H}_{2} \mathrm{O}$ and $\mathrm{NO}_{2}$ values are not very accurate in that case. Quantitative studies of the descent of $\mathrm{NO}_{2}$ from the mesosphere to the stratosphere can be affected somewhat by this $25 \mathrm{ppbv}$ limit, although time series of the retrieved $\mathrm{NO}_{2}$ for the upper stratosphere do not indicate any bias (see also Sect. 4.4). Further, it is noted that no screening threshold was applied to the retrieved $\mathrm{NO}_{2}$ of the polar mesosphere. Information about specific profile segments that were screened can be found on the LIMS Website (http://lims.gats-inc.com) for each day of the LIMS V6 dataset.

\subsection{Single profile error estimates}

The V6 $\mathrm{HNO}_{3}$ profile values are not much different from those of V5, except in the upper stratosphere where the interference from $\mathrm{CO}_{2}$ has been accounted for better in the V6 algorithm. In the tropical lower stratosphere there are important differences due to the corrections for emissions from the CFCs and due to the first-order correction for the aerosol 
emission. Random radiometric errors for $\mathrm{V} 6 \mathrm{HNO}_{3}$ are reduced from those of V5 by a factor of 2.2 because of the larger number of samples used with the interleave procedure for the retrieval of a V6 profile (Remsberg et al., 2004). Offset errors due to pointing jitter are included in those random uncertainties. The calculated precisions vary from $0.15 \mathrm{ppbv}$ at $80 \mathrm{hPa}$ to $0.05 \mathrm{ppbv}$ at $3 \mathrm{hPa}$, based on an average profile at $30^{\circ} \mathrm{S}$. Those calculated values are provided in percent in the top row of Table 1, and they compare well with empirical estimates of the precision from the Level 2 data themselves (the standard deviation (SD) profile in Fig. 4). The SD values were obtained as the minimum of the variances for each pressure level from among the sets of scans along each of the orbits that crossed $25^{\circ} \mathrm{S}$ to $35^{\circ} \mathrm{S}$ latitude on 1 February 1979. Of course, a part of the empirical SD values in Fig. 4 may be a result of real variations in the atmospheric $\mathrm{HNO}_{3}$.

Sources of systematic uncertainty were reported in Gille et al. (1984), based on simulations of their effects for V5 from a model $\mathrm{HNO}_{3}$ profile for $32^{\circ} \mathrm{N}$. Many of those error estimates are retained for V6, as shown in the middle rows of Table 1. However, the effects of temperature bias are based on the revised estimates of $\mathrm{T}(\mathrm{p})$ error in Remsberg et al. (2004). Uncertainty for the spectral band model is 5\%, according to Goldman et al. (1981). Uncertainties in the aerosol and CFC corrections are greatest for the tropical lower stratosphere but do not dominate the total error during 1978/1979. Biases at the tops of the $\mathrm{V}^{6} \mathrm{HNO}_{3}$ profiles are small because its a priori mixing ratio values are small near the stratopause, and they are applied above the pressure level of the first retrieved point, too. Uncertainties for the effects of the horizontal temperature gradients are not included, since sensitivity to temperature biases are relatively small for an optically thin species like $\mathrm{HNO}_{3}$.

The largest elements of potential bias error are the $\pm 20 \%$ uncertainties in the integrated areas of the field-of-view (FOV) side lobes and from a possible $0.05 \%$ bias in the total measured signal due to regions of the channel filter that are outside the main spectral band, as discussed in Gille et al. (1984) and shown in the bottom rows of Table 1. The FOV side lobes from the $\mathrm{HNO}_{3}$ channel are not all the same sign. To judge their effects, the measured $\mathrm{HNO}_{3}$ radiance profiles were analyzed at the vertical distances of the side lobes from the main $\mathrm{HNO}_{3}$ lobe or at effective separations of 17 and $34 \mathrm{~km}$ at the horizon. For instance, are there any positive or negative radiance correlations at those separations when the main lobe is viewing the low radiances of the mid to upper stratosphere and when the side lobes are viewing the much larger radiances at altitudes 17 or $34 \mathrm{~km}$ below? Our investigations indicated no significant correlations for $\mathrm{HNO}_{3}$ below $40 \mathrm{~km}$. Thus, it is concluded that the magnitude of that error in Table 1 must be an upper limit at all levels, except perhaps at $3 \mathrm{hPa}$. Uncertainties for the out-of-band spectral response can impart a positive bias in $\mathrm{HNO}_{3}$ of order $20 \%$ at $30 \mathrm{hPa}$, as pointed out in Gille et al. (1984). Yet, qualitative comparisons with other $\mathrm{HNO}_{3}$ datasets indicate agreement

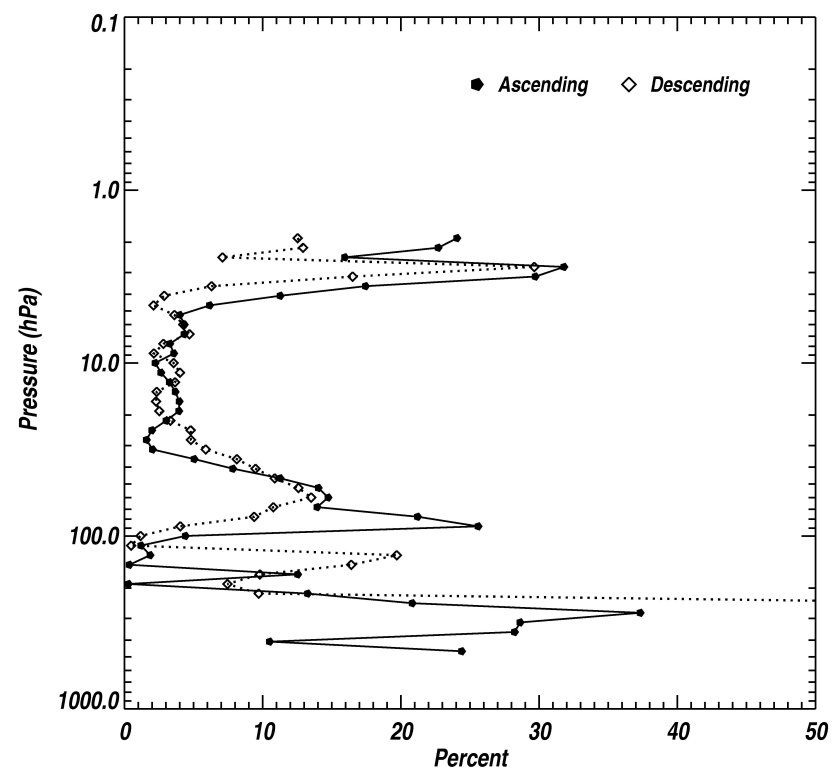

Fig. 4. Estimates of precision based on the minimum standard deviations (SD) of the retrieved LIMS V6 $\mathrm{HNO}_{3}$ profiles from the sets of ascending (solid) or descending (dashed) orbital crossings of the latitude band of $25^{\circ} \mathrm{S}$ and $35^{\circ} \mathrm{S}$ on 1 February 1979.

that is better than $20 \%$, at least for those datasets that were obtained at times of relatively low stratospheric aerosol loading. Therefore, neither of those sources of error is included in the combined root-sum-squares (RSS) calculations of accuracy in Table 1. In summary, the overall accuracy for V6 $\mathrm{HNO}_{3}$ is believed to be very good from $30 \mathrm{hPa}$ to $10 \mathrm{hPa}$ or of order $10 \%$ at middle latitudes.

Table 2 contains the calculations of precision and accuracy for the profiles of $\mathrm{NO}_{2}$. First, one is reminded that the nighttime values of $\mathrm{V} 6 \mathrm{NO}_{2}$ have peak mixing ratios near $4 \mathrm{hPa}$ that are about $15 \%$ to $20 \%$ lower than those of V5. Most of that change is due to the effects of the spectral spin splitting of the strong lines that were not considered for earlier versions of the AFGL or HITRAN line lists. On the other hand, the peak daytime $\mathrm{V} 6 \mathrm{NO}_{2}$ values at 8 to $10 \mathrm{hPa}$ are reduced from V5 by only about $5 \%$ because the effect of saturation for the strongest lines is not nearly so pronounced for the lower mixing ratios of daytime. In the upper stratosphere near $3 \mathrm{hPa}$, the daytime $\mathrm{V} 6 \mathrm{NO}_{2}$ is larger than that of V5 due to the improved determinations of the interfering V6 $\mathrm{H}_{2} \mathrm{O}$. Below the 30-hPa level of the lower stratosphere both the day and night $\mathrm{V} 6 \mathrm{NO}_{2}$ values are somewhat larger than V5. At this point it is noted that the V5 algorithm contained a merger of its retrieved $\mathrm{NO}_{2}$ with a balloon-based, average $\mathrm{NO}_{2}$ profile from $30^{\circ} \mathrm{N}$, constraining its results below the 30-hPa level at least when the $\mathrm{S} / \mathrm{N}$ for the tangent-layer radiance was low. The $\mathrm{V} 6 \mathrm{NO}_{2}$ algorithm is not constrained by any such climatological profile. 
Table 2. Calculations of precision and accuracy (\%) for LIMS V6 $\mathrm{NO}_{2}$.

\begin{tabular}{lllllll}
\hline Pressure (hPa) & 50 & 30 & 10 & 5 & 3 & 1 \\
\hline Noise and offset error & 5 & 5 & 3 & 3 & 3 & 14 \\
$\mathrm{H}_{2} \mathrm{O}$ interference & 3 & 3 & 3 & 3 & 5 & - \\
Random (Root-Sum- Squares or RSS Value - PRECISION) & 6 & 6 & 4 & 4 & 6 & 14 \\
Radiometric Bias Errors & 6 & 6 & 6 & 6 & 6 & 6 \\
Temperature Bias & 22 & 13 & 8 & 8 & 6 & 10 \\
$\mathrm{H}_{2} \mathrm{O}$ Mixing Ratio & 30 & 13 & 6 & 6 & 8 & 28 \\
$\mathrm{O}_{2}$ Cross Section (10\%) & 34 & 18 & 3 & 1 & 0 & 0 \\
$\mathrm{NO}_{2}$ Line Parameters (10\%) & 10 & 10 & 10 & 10 & 10 & 10 \\
Algorithm/Registration & 13 & 6 & 5 & 5 & 5 & 5 \\
Main FOV Lobe & 5 & 5 & 5 & 5 & 5 & 5 \\
RSS of Bias Errors (ACCURACY) & 53 & 29 & 18 & 18 & 17 & 33 \\
Unverified Source of Error (FOV Side Lobe Area) & 1 & 2 & 4 & 1 & 2 & 1 \\
\hline
\end{tabular}

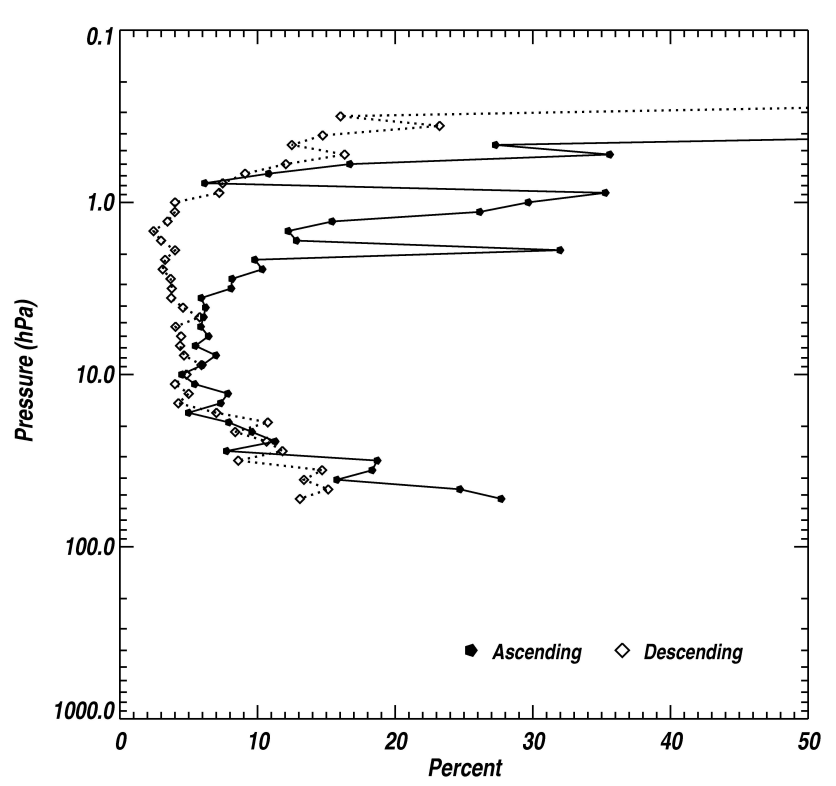

Fig. 5. As in Fig. 4, but for estimates of precision (SD) for LIMS V6 $\mathrm{NO}_{2}$ profiles.

The calculated precision values for the $\mathrm{V} 6 \mathrm{NO}_{2}$ in Table 2 were adopted from those of V5 in Russell et al. (1984a), after accounting for the improvements due to the use of all the samples within the measured radiance profiles. Random uncertainties from single profiles of the retrieved $\mathrm{H}_{2} \mathrm{O}$ were adopted from Remsberg et al. (2009) and are included because $\mathrm{H}_{2} \mathrm{O}$ is a major source of interfering emission, especially for daytime $\mathrm{NO}_{2}$ in the upper and the lowermost stratosphere. The effects of those random $\mathrm{H}_{2} \mathrm{O}$ errors are scaled further, according to the fraction of the signal in the $\mathrm{NO}_{2}$ channel that is due to $\mathrm{H}_{2} \mathrm{O}$. Estimates of percentage $\mathrm{NO}_{2}$ precision profiles from the data are shown in Fig. 5 and are based on average daytime and average nighttime SD profiles at $30^{\circ} \mathrm{S}$ for 1 February 1979 . Those values range from about
$5 \%$ in the middle stratosphere, to $8 \%$ for nighttime or $30 \%$ for daytime at $1 \mathrm{hPa}$, and then to $15-20 \%$ at $40 \mathrm{hPa}$. The estimated SD values in Fig. 5 agree with the RSS precisions in Table 2 for the middle and upper stratosphere but are larger at 30 and $50 \mathrm{hPa}$, presumably because of the effects of the natural variability of the atmospheric $\mathrm{NO}_{2}, \mathrm{H}_{2} \mathrm{O}$, and temperature.

A linear scaling was applied to the entries of the $\mathrm{V} 5 \mathrm{NO}_{2}$ error table in Russell et al. (1984a) for its V6 bias errors, based on a model-generated, daytime profile at $32^{\circ} \mathrm{N}$. Its primary sources of systematic uncertainty are from temperature bias and from the interfering effects of $\mathrm{H}_{2} \mathrm{O}$, based on the V6 uncertainties in Remsberg et al. (2004) and Remsberg et al. (2009), respectively. There are uncertainties in the lower stratosphere due to the $\mathrm{O}_{2}$ interference, but they should be considered as an upper limit because corrections for the $\mathrm{O}_{2}$ emission were applied to the retrievals of both the LIMS $\mathrm{H}_{2} \mathrm{O}$ and $\mathrm{NO}_{2}$ and therefore carry the same sign. There is also a possible bias due to a $20 \%$ uncertainty for the area of the measured FOV side lobes; its effect on the retrieved $\mathrm{NO}_{2}$ is believed to be small but remains unverified.

Table 2 indicates RSS V6 $\mathrm{NO}_{2}$ uncertainties of $17 \%$ at $3 \mathrm{hPa}$ and about $18 \%$ from 5 to $10 \mathrm{hPa}$. RSS values increase sharply in the lower stratosphere and are dominated by the estimates of error for the interfering $\mathrm{O}_{2}$ continuum and the $\mathrm{H}_{2} \mathrm{O}$. At stratopause levels $(1 \mathrm{hPa})$ the ascending (daytime) $\mathrm{NO}_{2}$ may have a bias of order $33 \%$ across most latitudes. However, the larger, descending (nighttime) $\mathrm{NO}_{2}$ values at that level are not affected much by the interfering $\mathrm{H}_{2} \mathrm{O}$, so they are more accurate $(\sim 17 \%)$. Also, the increasing values of $\mathrm{NO}_{2}$ in the lower mesosphere at the high northern latitudes of Fig. 3 are judged to be reasonably accurate (see also Sect. 4.4). One source of bias error that has been neglected is the likelihood that the retrieved V6 polar night $\mathrm{NO}_{2}$ values are too low in the mesosphere due to not accounting for the effects of non-LTE emissions of the ground-state of $\mathrm{NO}_{2}$ itself (e.g., see Funke et al., 2005a). 


\section{Scientific implications of the V6 data}

The previously, archived LIMS V5 $\mathrm{HNO}_{3}$ and $\mathrm{NO}_{2}$, along with the temperature, $\mathrm{O}_{3}$, and $\mathrm{H}_{2} \mathrm{O}$ data have been used in scientific studies and reported in the literature (e.g., Callis et al., 1983; Jackman et al., 1985; Natarajan et al., 1986; Solomon et al., 1986; and Considine et al., 1992). In the subsections that follow several of the issues that they raised with respect to the $\mathrm{V} 5 \mathrm{HNO}_{3}$ and $\mathrm{NO}_{2}$ profiles and distributions are re-visited and re-evaluated using the $\mathrm{V} 6$ data.

\section{1 $\mathrm{HNO}_{3} / \mathrm{NO}_{2}$ ratio profiles}

Simultaneous measurements of $\mathrm{HNO}_{3}$ and $\mathrm{NO}_{2}$ by LIMS provide an opportunity to check the partitioning of $\mathrm{NO}_{\mathrm{y}}$ species in comparison with that predicted with theoretical models. Notably, Jackman et al. (1985) reported that between 5 and $1 \mathrm{hPa}$ the ratio of the LIMS V5 daytime $\mathrm{HNO}_{3}$ to $\mathrm{NO}_{2}$ was inconsistent with model values and that $\mathrm{HNO}_{3}$ derived from photochemical relations should be used instead of those from LIMS. They based their conclusion on a comparison of daytime hydroxyl $(\mathrm{OH})$ values derived from the V5 data using two different procedures. In the first approach they invoked an instantaneous photochemical equilibrium assumption for $\mathrm{HNO}_{3}$ and, thereby, expressed $\mathrm{OH}$ concentrations as a function of the ratios of $\mathrm{HNO}_{3} / \mathrm{NO}_{2}$. Their second approach used an equilibrium assumption for odd hydrogen $\left(\mathrm{HO}_{\mathrm{x}}\right)$ along with the LIMS $\mathrm{O}_{3}$ and $\mathrm{H}_{2} \mathrm{O}$ data to derive the daytime $\mathrm{OH}$ values. In the upper stratosphere those two approaches yielded different results. For instance, the V5 $\mathrm{HNO}_{3} / \mathrm{NO}_{2}$ ratios overestimated $\mathrm{OH}$ in the upper stratosphere by a large margin, at least when compared to other available observations and model results. It is noted though that the lifetime of $\mathrm{HNO}_{3}$ against photolysis in the upper stratosphere is an hour or more, such that their instantaneous assumption is not strictly valid at the local measurement times of LIMS across all latitudes. Even so, their second approach yielded much better agreement with model $\mathrm{OH}$ values. Jackman et al. (1985) concluded that the problem with the first approach was due to errors in the LIMS $\mathrm{HNO}_{3}$ in the 5 to $1 \mathrm{hPa}$ region. Natarajan et al. (1986) reached a similar conclusion regarding the $\mathrm{HNO}_{3} / \mathrm{NO}_{2}$ ratio, but on the basis of diurnal photochemical model calculations that were constrained by the LIMS V5 nighttime data. The V5 $\mathrm{HNO}_{3} / \mathrm{NO}_{2}$ ratios also showed a positive bias in the upper stratosphere in comparison with their modeled daytime estimates.

Figure 6 is a comparison of the daytime ratio of V6 $\mathrm{HNO}_{3} / \mathrm{NO}_{2}$ for 15 February 1979 versus that from the updated, diurnal photochemical model of Natarajan et al. (2002), which incorporates the recommended chemical kinetics data of Sander et al. (2006). Distributions of longlived species, such as nitrous oxide $\left(\mathrm{N}_{2} \mathrm{O}\right)$ that are used to initialize the diurnal calculations are taken from a simulation with the NASA Langley two-dimensional model of Callis et al. (2001) using surface source gas mixing ratios correspond-
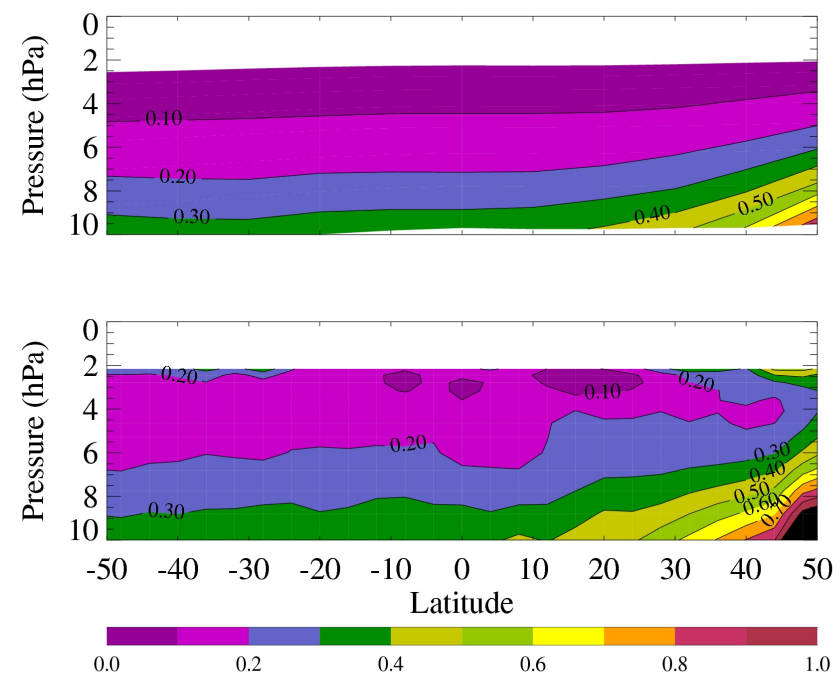

Fig. 6. $\mathrm{HNO}_{3} / \mathrm{NO}_{2}$ ratios for February 1979 - (top) model and (bottom) LIMS V6 data. Orange-to-red colors represent high ratios, while the magenta color shows low ratios.

ing to the 1978-1979 time period. The bottom panel of Fig. 6 shows LIMS $\mathrm{HNO}_{3} / \mathrm{NO}_{2}$ ratios that are less than 0.2 in the upper stratosphere to near $3 \mathrm{hPa}$, except at the winter high latitudes where the photochemical partitioning of the atmospheric $\mathrm{NO}_{\mathrm{y}}$ to $\mathrm{HNO}_{3}$ and $\mathrm{NO}_{2}$ is incomplete. In addition, at the top boundary of the data domain (near $2 \mathrm{hPa}$ ) the V6 ratios are lower than the ones from the V5 data (not shown). The better determinations of the V6 temperature profile and its effects for the laser band of $\mathrm{CO}_{2}$ have led to a large decrease in the retrieved, upper stratospheric $\mathrm{HNO}_{3}$ and a corresponding decrease in the $\mathrm{HNO}_{3} / \mathrm{NO}_{2}$ ratio. The model results are shown in the top panel of Fig. 6, and they agree well with the ratios from the V6 data.

The $\mathrm{HNO}_{3} / \mathrm{NO}_{2}$ ratios in Fig. 6 from both the model and LIMS are declining from $10 \mathrm{hPa}$ to about $3 \mathrm{hPa}$, but then the LIMS ratios become larger than the model values at the topmost boundary. The reason for the remaining disagreement near $2 \mathrm{hPa}$ is most likely a high bias in the daytime $\mathrm{HNO}_{3}$ due to the influence of non-LTE emission in the spectrallybroad, LIMS channel that has not been corrected. Edwards et al. (1996) also observed differences between the day and night radiances from the $10.83-\mu \mathrm{m}$ blocker channel of the Cryogenic Limb Array Etalon Spectrometer (CLAES) instrument, and they ascribed them to non-LTE effects from ozone and $\mathrm{CO}_{2}$ near the stratopause during daytime. Estimates of the effects of those emissions on the retrieved LIMS $\mathrm{HNO}_{3}$ have not been evaluated for this paper. Nevertheless, because of the improved results from LIMS V6 there is no longer any need to substitute model $\mathrm{HNO}_{3}$ for the retrieved LIMS daytime values throughout most of the upper stratosphere. 


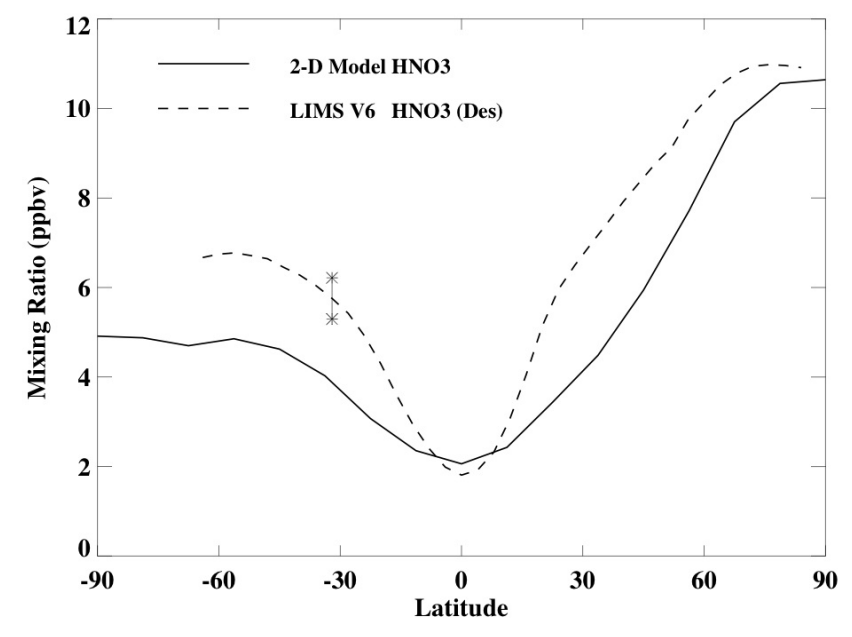

Fig. 7. LIMS V6 (dashed) and model (solid) comparisons for $\mathrm{HNO}_{3}$ in ppbv from the LIMS descending (Des or nighttime) orbital segments of December 1978. The vertical line on the LIMS data at $32^{\circ} \mathrm{S}$ denotes its estimated uncertainty.

\subsection{Lower stratospheric $\mathrm{HNO}_{3}$ and $\mathrm{NO}_{2}$}

The LIMS dataset provides global scale information on the latitudinal distribution of stratospheric $\mathrm{HNO}_{3}$ and $\mathrm{NO}_{2}$. Earlier analyses of the V5 data in conjunction with model studies highlighted a deficiency with respect to the $\mathrm{HNO}_{3}$ mixing ratios of the winter high latitudes as calculated by models using only gas-phase chemistry. For instance, Austin et al. (1986) compared LIMS V5 $\mathrm{HNO}_{3}$ with other measurements and model results. They reported that an additional source of $\mathrm{HNO}_{3}$ was needed at high latitudes in winter and suggested that the hydrolysis of $\mathrm{N}_{2} \mathrm{O}_{5}$ on aerosol surfaces could be important. Considine et al. (1992) also described results from their two-dimensional model compared with the V5 data and noted the importance of heterogeneous chemistry for their calculations of $\mathrm{HNO}_{3}$. They also pointed out that while the inclusion of heterogeneous chemistry improved the model/data agreement for $\mathrm{HNO}_{3}$, its addition led to larger discrepancies between the calculated and observed $\mathrm{NO}_{2}$.

At this point it is noted that the latitudinal variations from the V6 algorithm are similar to those from V5 for middle and lower stratospheric $\mathrm{HNO}_{3}$ and for $\mathrm{NO}_{2}$ (at least above the 30-hPa level). Their profile variations in the middle to lower stratosphere are also similar to the results (not shown) from more recent satellite experiments (e.g., Santee et al., 2007; Wetzel et al., 2007; Kyröla et al., 2010). These results are not surprising because the updated spectral parameters for the primary gases of V6 have little effect on their retrieved mixing ratios at those altitudes. However, changes from V5 to V6 were found in the lower stratosphere at tropical and polar winter latitudes, due to improvements in their associated profiles of $T(p)$ and interfering species.
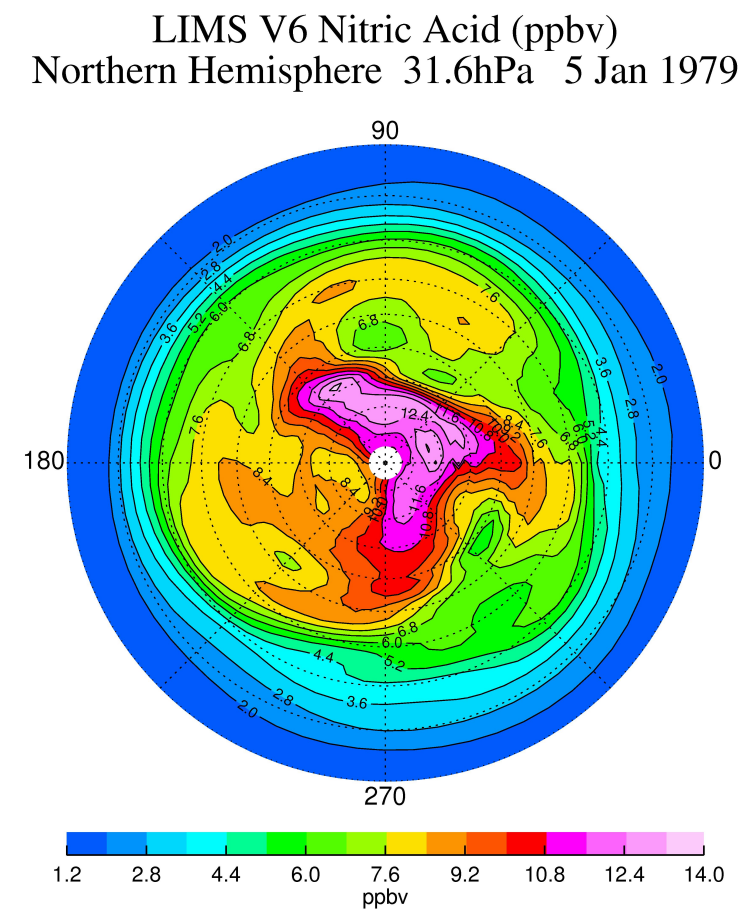

Fig. 8. Ascending plus descending $\mathrm{V} 6 \mathrm{HNO}_{3}$ in ppbv for 5 January 1979. Bluish regions are low values and orange-to-pink regions are high values; contour interval is $0.8 \mathrm{ppbv}$.

Figure 7 shows a comparison of zonally averaged $\mathrm{HNO}_{3}$ at $30 \mathrm{hPa}$ as a function of latitude for December 1978. The dashed line represents LIMS V6 data, and the solid line corresponds to the $\mathrm{HNO}_{3}$ from the two-dimensional model of Callis et al. (2001). The model includes heterogeneous processing of $\mathrm{N}_{2} \mathrm{O}_{5}$ and $\mathrm{ClONO}_{2}$ on stratospheric sulfate aerosol surfaces, leading to the production of $\mathrm{HNO}_{3}$. Reaction probabilities were adopted for the model from Sander et al. (2006). The surface area densities for the background aerosol distribution were taken from the climatology based on SAGE II measurements (Thomason et al., 1997). The model does not include reactions on polar stratospheric cloud particles. A heterogeneous reaction path explains the higher mixing ratios at the winter high latitudes and the good agreement with the LIMS data.

The vertical line in Fig. 7 represents the estimated LIMS uncertainty of $8 \%$ based on a mid-latitude summer profile

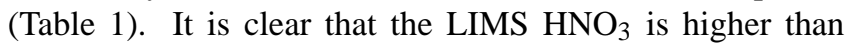
that of the model across the middle latitudes and has a different slope, particularly for the winter hemisphere. Figure 8 shows the V6 $\mathrm{HNO}_{3}$ distribution on the $31.6 \mathrm{hPa}$ surface of the northern hemisphere for early January 1979, and it exhibits a zonal wave-3 variation at middle and high latitudes. Remsberg and Bhatt (1996) indicated that the effects of such zonal wave activity could lead to the pattern of the middle latitude surf zone plus a subtropical barrier region by early January, as shown in Fig. 8. It is difficult to simulate such 
wave forcing and subsequent changes of the $\mathrm{HNO}_{3}$ distribution with the parameterized transport of a two-dimensional model. Thus, while the model results indicate the proper seasonal variations at the high latitudes, they do not agree well in the middle latitudes with the early January data at this pressure level. In the tropics the observed $\mathrm{HNO}_{3}$ in Fig. 8 displays almost no zonal variations; Fig. 7 shows that the LIMS data and model results agree well in that region.

Figure 9 is a polar plot of the northern hemisphere distribution of LIMS V6 nighttime $\mathrm{NO}_{2}$ at $31.6 \mathrm{hPa}$ for 5 January 1979 . Note that the distribution shows a decrease along the $270^{\circ} \mathrm{E}$ meridian from about $2.4 \mathrm{ppbv}$ at $30^{\circ} \mathrm{N}$ to less than $1.0 \mathrm{ppbv}$ by about $50^{\circ} \mathrm{N}$. This change is a clear indication of the so-called "cliff phenomenon" in column $\mathrm{NO}_{2}$ over North America (Noxon, 1979). Such a pronounced variation with latitude was not as apparent and coherent within the V5 dataset. One can now readily follow the daily evolution of this feature and compare it with the changes in $\mathrm{HNO}_{3}$ using the V6 data.

\subsection{Day-to-night $\mathrm{NO}_{2}$ ratios}

The availability of daytime and nighttime measurements of a diurnally varying species like $\mathrm{NO}_{2}$ allows one to examine the photochemistry of this species using theoretical models in conjunction with data. For example, Solomon et al. (1986) used LIMS nighttime $\mathrm{NO}_{2}$ data at high northern latitudes in May to show that the decay of $\mathrm{NO}_{2}$ to form $\mathrm{N}_{2} \mathrm{O}_{5}$ was consistent with theory. On the other hand, Kerridge and Remsberg (1989) examined profiles of the day-to-night ratios of $\mathrm{NO}_{2}$ and found a region of discrepancy with theory in the upper stratosphere. In particular, the LIMS V5 data showed much larger ratios than expected from photochemical models above about $42 \mathrm{~km}$ (or the 2 -hPa level).

An updated comparison of the day-to-night $\mathrm{NO}_{2}$ ratio profiles from the V6 dataset is shown in Fig. 10 along with those from a contemporary, diurnal photochemical model. The model is an updated version of the zero-dimensional model described in Natarajan et al. (2002) and Natarajan and Callis (1991). The numerical procedure uses a stiff equation solver to integrate the system of species continuity equations. Chemical kinetics and photochemical data are adopted from Sander et al. (2006). For each latitude and altitude location considered, the model is constrained by the nighttime observations of LIMS. Initialization for species that are not measured by LIMS, for example chlorine species, is based on the results of the two-dimensional model of Callis et al. (2001). During initialization, the calculations are repeated for a few diurnal cycles, and in each cycle at the local time corresponding to the LIMS nighttime measurement the mixing ratios of the observed species are reset to the measured values. Once the unmeasured reactive species reach a steady diurnal variation, the time integration is continued for another diurnal cycle and the required parameters are evaluated, i.e., the day/night ratios for $\mathrm{NO}_{2}$.
LIMS V6 Nitrogen Dioxide (ppbv) Desc Northern Hemisphere 31.6hPa 5 Jan 1979

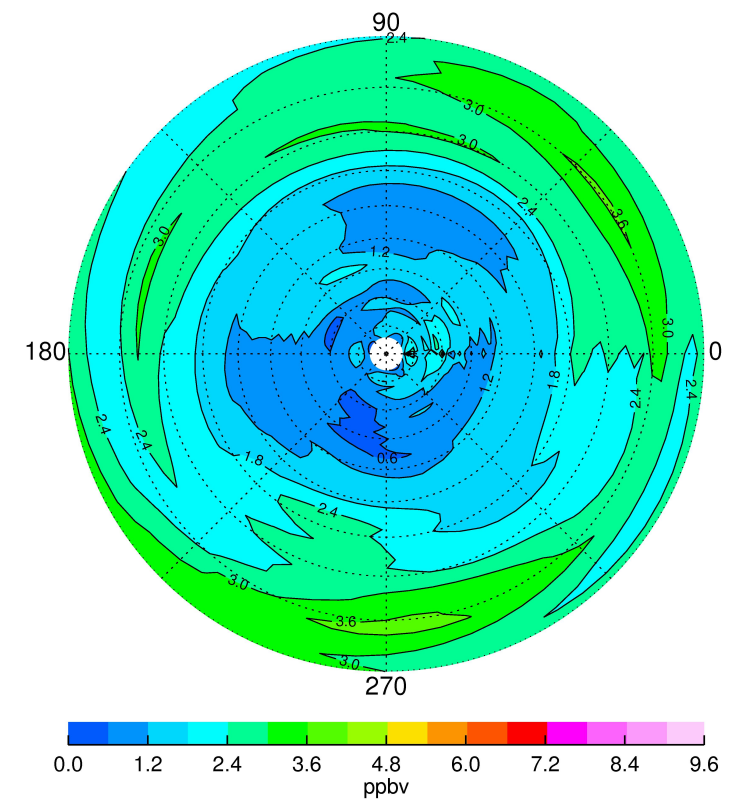

Fig. 9. V6 descending $\mathrm{NO}_{2}$ in ppbv for 5 January 1979. Bluish regions are low values and greenish regions are high values; contour interval is $0.6 \mathrm{ppbv}$.

The monthly-averaged LIMS results for May 1979 are in the bottom panel of Fig. 10, and they show steadily declining ratios above the 5-hPa level, reaching a minimum of less than 0.05 at $1.0 \mathrm{hPa}$ but then increasing to about 0.15 at $0.5 \mathrm{hPa}$. The model day-to-night $\mathrm{NO}_{2}$ ratios are shown in the top panel and correspond to the local times of the LIMS day and night measurements. The model ratios are in good agreement with the data in the 5 to $1 \mathrm{hPa}$ region but continue to show decreasing values in the lower mesosphere. Interfering radiance from $\mathrm{H}_{2} \mathrm{O}$ is the primary source of uncertainty for the LIMS forward model of $\mathrm{NO}_{2}$ in the mesosphere, especially for daytime. $\mathrm{H}_{2} \mathrm{O}$ was accounted for by considering the retrieved $\mathrm{H}_{2} \mathrm{O}$ up to $1.5 \mathrm{hPa}$ plus a fixed $\mathrm{H}_{2} \mathrm{O}$ value above that level, even though non-LTE emissions from $\mathrm{H}_{2} \mathrm{O}$ are known to be important (Remsberg et al., 2009). As with V5, the LIMS V6 algorithm does not correct for such nonLTE effects in $\mathrm{H}_{2} \mathrm{O}$, leading to a positive bias in the retrieved daytime $\mathrm{NO}_{2}$. Funke et al. (2005a) found no evidence for non-LTE emissions from the higher-vibrational states of $\mathrm{NO}_{2}$ itself in the MIPAS data, at least for altitudes below $50 \mathrm{~km}$. Whether there may be such effects from $\mathrm{NO}_{2}$ in the lower mesosphere is unclear. It is tentatively concluded that any non-LTE effects from $\mathrm{NO}_{2}$ in the mesosphere are secondary to the influence of the non-LTE emissions from $\mathrm{H}_{2} \mathrm{O}$, and it is estimated that the upper boundary region of accurate V6 daytime $\mathrm{NO}_{2}$ values is 1.5 to $1.0 \mathrm{hPa}$. 

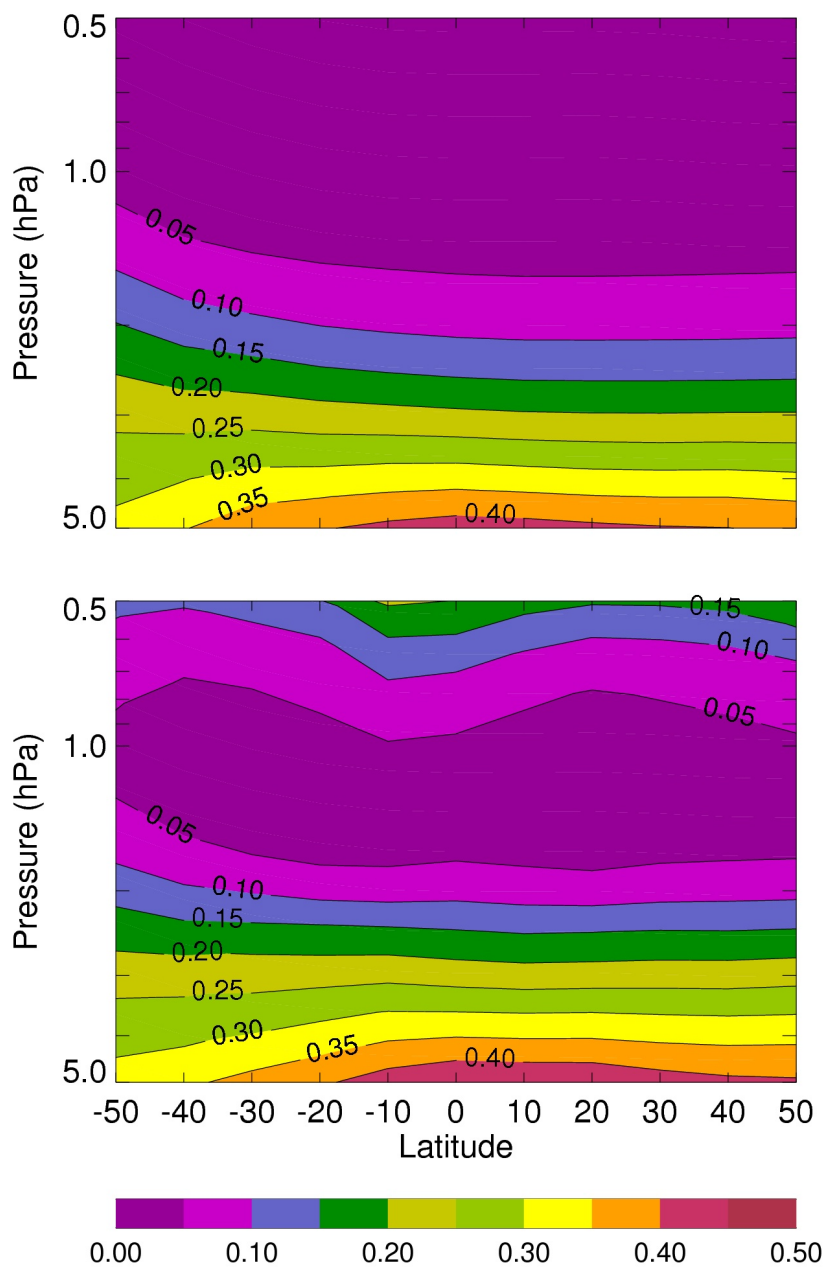

Fig. 10. Ascending/descending (or day/night) $\mathrm{NO}_{2}$ ratio (top) from the diurnal model and (bottom) from the LIMS V6 data. Orangeto-red colors are high ratios, while magenta colors are low ratios.

\subsection{Mesospheric $\mathrm{NO}_{2}$ during polar night}

The production of $\mathrm{NO}_{\mathrm{x}}$ in the mesosphere and lower thermosphere by energetic particle precipitation has been described in connection with its downward transport into the high latitude winter stratosphere (e.g., Callis et al., 2001; Natarajan et al., 2004; Funke et al., 2005b; Randall et al., 2006). Russell et al. (1984b) reported the first satellite-based observation of wintertime increases in upper stratospheric $\mathrm{NO}_{2}$. Upon averaging 5 days of LIMS radiances within $60^{\circ}$ longitude sectors, they were able to extend their retrievals of LIMS $\mathrm{NO}_{2}$ to higher altitudes. By focusing on polar night conditions in January 1979 , they obtained $\mathrm{NO}_{2}$ mixing ratios exceeding $100 \mathrm{ppbv}$ in one $60^{\circ}$ sector of the lower mesosphere. Odd nitrogen can be produced directly by solar proton events in the high latitude upper stratosphere. However, the study by Jackman et al. (1990) for the period 1963-1984 does not indicate the occurrence of any such event during January 1979. The

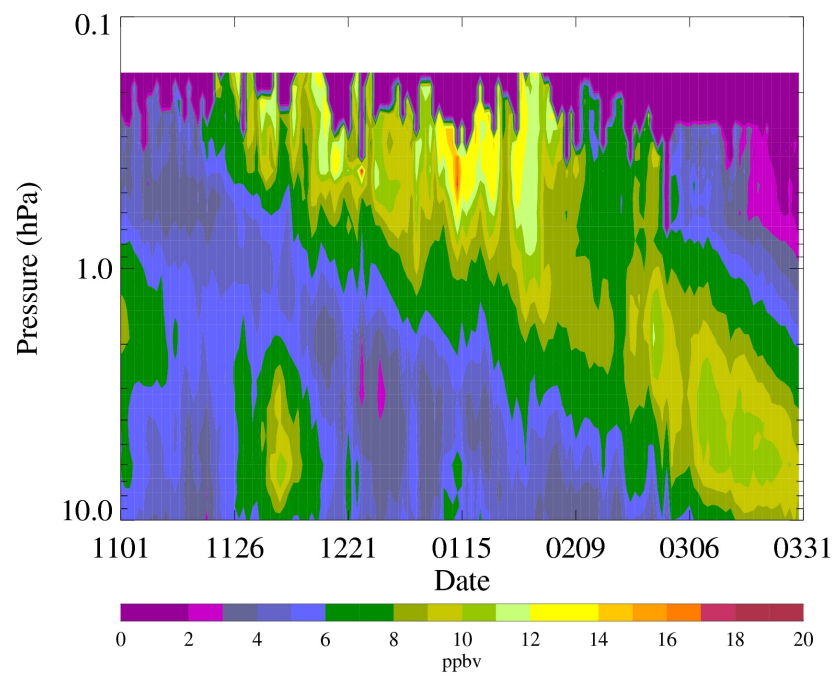

Fig. 11. Time series of LIMS V6 descending (or nighttime) $\mathrm{NO}_{2}$ in ppbv for latitudes $>74^{\circ} \mathrm{N}$. The time span is from 1 November 1978 (1101) to 31 March 1979 (0331). For those few days when no data were taken, the $\mathrm{NO}_{2}$ values are averages from the adjacent days. Yellow colors are high values, while blue-to-magenta colors are low values.

enhanced $\mathrm{NO}_{2}$ in the LIMS data must be due to high latitude descent within the mesosphere following the production of $\mathrm{NO}_{\mathrm{x}}$ by energetic particle precipitation, the so-called "indirect effect" (Randall et al., 2006).

The V6 algorithm does not employ a radiance-averaging procedure, so the single profiles of $\mathrm{V}^{6} \mathrm{NO}_{2}$ extend only up to about $0.15 \mathrm{hPa}$ at the winter high latitudes. Although elevated, zonally-averaged mixing ratios of $\mathrm{NO}_{2}$ are still found in the mesosphere (Fig. 3), they are lower than those reported in Russell et al. (1984). Even so, the V6 values are considerably higher than what is expected if there are only stratospheric sources of $\mathrm{NO}_{\mathrm{x}}$. The occurrence of the smaller $\mathrm{NO}_{2}$ mixing ratios from $\mathrm{V} 6$ is primarily because the $\mathrm{V} 6$ radiance profiles are registered better and the V6 temperatures are warmer by as much as $6 \mathrm{~K}$ at $0.1 \mathrm{hPa}$ (Remsberg et al., 2004). Although the single profile error estimates for $\mathrm{NO}_{2}$ in Table 2 apply strictly to its climatological profile and do not extend to altitudes above $1 \mathrm{hPa}$, the effects of a $2 \mathrm{~K}$ temperature bias and of an $\mathrm{H}_{2} \mathrm{O}$ bias at $1 \mathrm{hPa}$ are $10 \%$ and $28 \%$, respectively. Total error in Table 2 for $\mathrm{NO}_{2}$ is estimated to be $33 \%$ at $1 \mathrm{hPa}$. However, the EOS Aura MLS experiment confirms that $\mathrm{H}_{2} \mathrm{O}$ has relatively small values in the wintertime, polar vortex regions of the mesosphere (http://mls.jpl.nasa.gov/). Thus, the uncertainties for the LIMS V6 $\mathrm{NO}_{2}$ from Table 2 due to the interfering effects of $\mathrm{H}_{2} \mathrm{O}$ should be reduced considerably for the polar night.

Figure 11 is a time series of the zonally-averaged V6 descending node (or nighttime) $\mathrm{NO}_{2}$ mixing ratio as a function of pressure for latitudes greater than $74^{\circ} \mathrm{N}$. Data from 1 November 1978 to 31 March 1979 are shown. For the 
several days when the LIMS instrument did not take data, their $\mathrm{NO}_{2}$ values are averages from the adjacent days at all pressure levels. $\mathrm{NO}_{2}$ mixing ratios exceeding $10 \mathrm{ppbv}$ occurred in the 0.2 to $0.5 \mathrm{hPa}$ region from late November 1978 to early February 1979 along with a clear indication of atmospheric descent with time of that elevated $\mathrm{NO}_{2}$. Comparisons of the fields of geopotential height and nighttime $\mathrm{NO}_{2}$ during January at $0.46 \mathrm{hPa}$ indicate that the highest $\mathrm{NO}_{2}$ values correspond to observations within the polar vortex region (not shown). The reaction of $\mathrm{NO}_{\mathrm{x}}$ with $\mathrm{O}_{3}$ in the upper stratosphere leads to a gradual conversion of $\mathrm{NO}_{2}$ to nitrogen trioxide $\left(\mathrm{NO}_{3}\right)$ and then to $\mathrm{N}_{2} \mathrm{O}_{5}$ in the polar night region. During November and December and between 2 and $10 \mathrm{hPa}$, the $\mathrm{NO}_{2}$ variations in Fig. 11 are mostly a result of transport of air from lower latitudes followed by the photochemical conversion of its $\mathrm{NO}_{2}$. In particular, early December 1978 was the time of a wave-1, stratospheric (Canadian) warming event. The LIMS observations of Fig. 11 provide support for the hypothesis that under such dynamic conditions there can be increases of high-latitude, upper stratospheric $\mathrm{NO}_{\mathrm{x}}$ as a result of accelerated descent within the polar vortex. More dramatic perturbations, such as solar proton events, are not a necessary condition for moderate enhancements of upper stratospheric $\mathrm{NO}_{\mathrm{x}}$.

\section{Summary findings}

The radiances of the Nimbus 7 LIMS experiment were reconditioned and new retrievals of them conducted with an updated (V6) algorithm to generate $\mathrm{HNO}_{3}$ and $\mathrm{NO}_{2}$ profiles that are more compatible with those of follow-on satellite experiments. The $\mathrm{V}^{6} \mathrm{HNO}_{3}$ profiles are nearly unchanged in the middle and lower stratosphere from those of the earlier V5 algorithm. However, in the upper stratosphere V6 $\mathrm{HNO}_{3}$ is smaller due to improvements in the accounting for interfering emissions from $\mathrm{CO}_{2}$. That change yields daytime $\mathrm{HNO}_{3} / \mathrm{NO}_{2}$ ratios that agree better with results from theoretical model calculations than before. The V6 $\mathrm{NO}_{2}$ profiles have smaller values than those of V5, most noticeably for nighttime in the upper stratosphere due to the accounting of spin-rotation effects within the updated, spectroscopic line parameters of $\mathrm{NO}_{2}$. More accurate retrievals of the $\mathrm{V} 6$ temperature and $\mathrm{H}_{2} \mathrm{O}$ from the lower mesosphere to near the stratopause are responsible for the more realistic V6 $\mathrm{NO}_{2}$ profiles of that region of the atmosphere, most notably in the polar night regions. Day-to-night ratios of $\mathrm{V} 6 \mathrm{NO}_{2}$ also agree well with photochemical model calculations in the middle and upper stratosphere.

Individual V6 profiles of $\mathrm{HNO}_{3}$ and $\mathrm{NO}_{2}$ have points every $0.375 \mathrm{~km}$ and an effective vertical resolution of $3.7 \mathrm{~km}$. The V6 retrievals were applied to adjacent pairs of profiles along orbits, yielding a spacing of 1.6 degrees of latitude between retrieved profiles, on average. Single $\mathrm{HNO}_{3}$ profiles have calculated precisions of $3-4 \%$ from 10 to $50 \mathrm{hPa}$ but of order $10 \%$ at $3 \mathrm{hPa}$ and $21 \%$ at $80 \mathrm{hPa}$. Single $\mathrm{NO}_{2}$ profiles have precisions of about $3 \%$ from 3 to $10 \mathrm{hPa}, 7 \%$ at 30 to $50 \mathrm{hPa}$, and $14 \%$ at $1 \mathrm{hPa}$. The improved precisions and more frequent retrievals of profiles along the orbit tracks provide better continuity and detail for map analyses of these two species on pressure surfaces.

Calculated accuracies for single profiles of $\mathrm{V} 6 \mathrm{HNO}_{3}$ are better than $10 \%$ from 10 to $50 \mathrm{hPa}$, and about $12 \%$ at $3 \mathrm{hPa}$ and $16 \%$ at $80 \mathrm{hPa}$. Accuracy for the $\mathrm{V} 6 \mathrm{NO}_{2}$ profiles is of order $18 \%$ from 3 to $10 \mathrm{hPa}$, but degrades to about $30 \%$ at $30 \mathrm{hPa}$ and $1 \mathrm{hPa}$. Even so, good quality retrievals of $\mathrm{V} 6 \mathrm{NO}_{2}$ extend downward to at least the 50-hPa level at polar latitudes in northern winter, which was not the case for $\mathrm{NO}_{2}$ from the earlier V5 dataset. A time series plot of $\mathrm{V} 6 \mathrm{NO}_{2}$ at northern high latitudes illustrates $\mathrm{NO}_{\mathrm{x}}$ enhancement, most likely due to wintertime descent from the lower mesosphere to the upper stratosphere. This finding is significant, especially when one considers that there were no large solar disturbances or enhanced geomagnetic storm activity in late 1978 or early 1979.

The V6 $\mathrm{HNO}_{3}$ distributions still support the finding that one must include heterogeneous chemical mechanisms in stratospheric models for the partitioning of $\mathrm{NO}_{\mathrm{y}}$, even during the 1978-1979 period of low volcanic aerosol loading. However, it is also apparent from the V6 data that there are deficiencies for the seasonal, meridional transport of the $\mathrm{N}_{2} \mathrm{O}$ source molecule and/or of its end product $\mathrm{NO}_{\mathrm{y}}$, as simulated with a two-dimensional model of the lower stratosphere.

The V6 Level 2 (profile) data can be obtained by ftp download from the Goddard Earth Sciences and Data Information Services Center or GES DISC (http://daac.gsfc.nasa.gov/). A LIMS V6 Level 3 or zonal Fourier coefficient product is also available at GES DISC (Remsberg and Lingenfelser, 2010).

Acknowledgements. We recognize the extensive efforts of John Gille and Jim Russell III (Co-PIs) and the members of the original Project and Science Teams for their development and conduct of the LIMS experiment. Yun-fei Wang conducted analyses of the LIMS $\mathrm{HNO}_{3}$ radiances for evidence of any spurious effects from its FOV side lobes. The comments and suggestions from the two anonymous reviewers of the manuscript have been helpful and are appreciated. The research leading to the improvement and generation of the LIMS V6 Level 2 dataset was conducted with the consistent support of Jack Kaye of NASA Headquarters. The archival of the LIMS Level 3 product and the analyses in this manuscript were supported with funds from the NASA NRA NNH08ZDA001N of the MAP Program administered by David Considine.

Edited by: W. Lahoz 


\section{References}

Austin, J., Garcia, R. R., Russell III, J. M., Solomon, S., and Tuck, A. F.: On the atmospheric photochemistry of nitric acid, J. Geophys. Res., 91, 5447-5485, 1986.

Bekki, S., Chipperfield, M. A., Pyle, J. A, Remedios, J. J., Smith, S. E., Grainger, R. G., Lambert, A., Kumer, J. B., and Mergenthaler, J. L.: Coupled aerosol-chemical modeling of UARS $\mathrm{HNO}_{3}$ and $\mathrm{N}_{2} \mathrm{O}_{5}$ measurements in the Arctic upper stratosphere, Geophys. Res. Lett., 102, 8977-8984, 1997.

Butchart, N. and Remsberg, E. E.: The area of the stratospheric polar vortex as a diagnostic for tracer transport on an isentropic surface, J. Atmos. Sci., 43, 1319-1339, 1986.

Callis, L. B., Natarajan, M., and Lambeth, J. D.: Solar-atmospheric coupling by electrons (SOLACE) 3. Comparisons of simulations and observations, 1979-1997, issues and implications, J. Geophys. Res., 106, 7523-7539, 2001.

Callis, L. B., Russell III, J. M., Haggard, K. V., and Natarajan, M.: Examination of wintertime latitudinal gradients in stratospheric $\mathrm{NO}_{2}$ using theory and LIMS observations, Geophys. Res., Lett., 10, 945-948, 1993.

Considine, D. B., Douglass, A. R., and Stolarski, R. S.: Heterogeneous conversion of $\mathrm{N}_{2} \mathrm{O}_{5}$ to $\mathrm{HNO}_{3}$ on background stratospheric aerosols: comparisons of model results with data, Geophys. Res. Lett., 19, 397-400, 1992.

Dana, V., Mandin, J.-Y., Guelachvili, G., Kou, Q., MorillonChapey, M., Wattson, R. B., and Rothman, L. S.: Intensities and self-broadening coefficients of ${ }^{12} \mathrm{C}^{16} \mathrm{O}_{2}$ lines in the laser band region, J. Mol. Spectroscopy, 152, 328-241, 1992.

Drayson, S. R., Bailey, P. L., Fischer, H., Gille, J. C., Girard, A., Gordley, L. L., Harries, J. E., Planet, W. G., Remsberg, E. E., and Russell III, J. M.: Spectroscopy and transmittances for the LIMS experiment, J. Geophys. Res., 89, 5141-5146, 1984.

Edwards, D. P., Kumer, J. B., Lopez-Puertas, M., Mlynczak, M. G., Gopalan, A., Gille, J. C., and Roche, A.: Non-local thermodynamic equilibrium limb radiance near $10 \mu \mathrm{m}$ as measured by UARS CLAES, J. Geophys. Res., 101, 26577-26588, 1996.

Froidevaux, L., Allen, M., Berman, S., and Daughton, A.: The mean ozone profile and its temperature sensitivity in the upper stratosphere and lower mesosphere: an analysis of LIMS observations, J. Geophys. Res., 94(D5), 6389-6417, 1989.

Funke, B., Lopez-Puertas, M., von Clarmann, T., Stiller, G. P., Fischer, H., Glatthor, N., Grabowski, U., Hoepfner, M., Kellmann, S., Kiefer, M., Linden, A., Mengistu Tsidu, G., Milz, M., Steck, T., and Wang, D.-Y.: Retrieval of stratospheric $\mathrm{NO}_{\mathrm{x}}$ from 5.3 and $6.2 \mu \mathrm{m}$ nonlocal thermodynamic equilibrium emissions measured by Michelson Interferometer for Passive Atmospheric Sounding (MIPAS) on Envisat, J. Geophys. Res., 110, D09302, doi:10.1029/2004JD005225, 2005a.

Funke, B., Lopez-Puertas, M., Gil-Lopez, S., von Clarmann, T., Stiller, G. P., Fischer, H., and Kellmann, S.: Downward transport of upper atmospheric $\mathrm{NO}_{\mathrm{x}}$ into the polar stratosphere and lower mesosphere during the Antarctic 2003 and Arctic 2002/2003 winters, J. Geophys. Res., 110, D24308, doi:10.1029/2005JD006463, 2005b.

Gille, J. C.: Distributions of ozone and nitric acid measured by the limb infrared monitor of the stratosphere (LIMS), in Transport Processes in the Middle Atmosphere, edited by: Visconti, G. and Garcia, R., D. Reidel Publ. Co., Dordrecht, Holland, 73-85, 1987.
Gille, J. C. and Russell III, J. M.: The limb infrared monitor of the stratosphere: experiment description, performance, and results, J. Geophys. Res., 89, 5125-5140, 1984.

Gille, J. C., Bailey, P. L., and Craig, C. A.: Revised reference model for nitric acid, Adv. Space Res., 13, 59-72, 1993.

Gille, J. C., Russell III, J. M., Bailey, P. L., Remsberg, E. E., Gordley, L. L., Evans, W. F. J., Fischer, H., Gandrud, B. W., Girard, A., Harries, J. E., and Beck, S. A.: Accuracy and precision of the nitric acid concentrations determined by the limb infrared monitor of the stratosphere experiment on NIMBUS 7, J. Geophys. Res., 89, 5179-5190, 1984.

Giver, L. P., Valero, P. J., and Goorvitch, D.: Nitric acid band intensities and band-model parameters from 620 to $1760 \mathrm{~cm}^{-1}, \mathrm{~J}$. Opt. Soc. Am. B, 1, 715-722, 1984.

Goldman, A., Bonomo, F. S., Valero, F. P. J., Goorvitch, D., and Boese, R. W.: Temperature dependence of $\mathrm{HNO}_{3}$ absorption in the 11.3- $\mu \mathrm{m}$ region, Appl. Opt., 20, 172-175, 1981.

Gordley, L. L., and Russell III, J. M.: Rapid inversion of limb radiance data using an emissivity growth approximation, Appl. Opt., 20, 807-813, 1981.

Hervig, M. E., Russell III, J. M., Gordley, L. L., Daniels, J., Drayson, S. R., and Park, J. H.: Aerosol effects and corrections in the Halogen Occultation Experiment, J. Geophys. Res., 100, 1067-1079, 1995.

Hitchman, M. A., McKay, M., and Trepte, C. R.: A climatology of stratospheric aerosol, J. Geophys. Res., 99, 20689-20700, 1994.

Jackman, C. H., Douglass, A. R., Rood, R. R., McPeters, R. D., and Meade, P. E.: Effect of solar proton events on the middle atmosphere during the past two solar cycles as computed using a two-dimensional model, J. Geophys. Res., 95, 7417-7428, 1990.

Jackman, C. H., Kaye, J. A., and Guthrie, P. D.: LIMS $\mathrm{HNO}_{3}$ data above 5 mbar: corrections based on simultaneous observations of other species, J. Geophys. Res., 90, 7923-7930, 1985.

Jensen, E. and Drdla, K.: Nitric acid concentrations near the tropical tropopause: implications for the properties of tropical nitric acid trihydrate clouds, Geophys. Res. Lett., 29, 2001, doi:10.1029/2002GL015190, 2002.

Kawa, S. R., Kumer, J. B., Douglass, A. R., Roche, A. E., Smith, S. E., Taylor, F. W., and Allen, D. J.: Missing chemistry of reactive nitrogen in the upper stratospheric polar winter, Geophys. Res. Lett., 22, 2629-2632, 1995.

Kerridge, B. J. and Remsberg, E. E.: Evidence from the limb infrared monitor of the stratosphere for nonlocal thermodynamic equilibrium in the $v_{2}$ mode of mesospheric water vapour and the $v_{3}$ mode of stratospheric nitrogen dioxide, J. Geophys. Res., 94, 16323-16342, 1989.

Kyrölä, E., Tamminen, J., Sofieva, V., Bertaux, J. L., Hauchecorne, A., Dalaudier, F., Fussen, D., Vanhellemont, F., Fanton d'Andon, O., Barrot, G., Guirlet, M., Fehr, T., and Saavedra de Miguel, L.: GOMOS $\mathrm{O}_{3}, \mathrm{NO}_{2}$, and $\mathrm{NO}_{3}$ observations in 2002-2008, Atmos. Chem. Phys. Discuss., 10, 2169-2220, doi:10.5194/acpd10-2169-2010, 2010.

Leovy, C. B., Sun, C.-R., Hitchman, M. H., Remsberg, E. E., Russell, III, J. M., Gordley, L. L., Gille, J. C., and Lyjak, L. V.: Transport of ozone in the middle stratosphere: evidence for planetary wave breaking, J. Atmos. Sci., 42, 230-244, 1985.

Lopez-Puertas, M. and Taylor, F. W.: Non-LTE radiative transfer in the atmosphere, World Scientific Publishing Co. Pte. Ltd., London, 487 pp., 2001. 
Mlynczak, M. G., Mertens, C. J., Garcia, R. R., and Portmann, R. W.: A detailed evaluation of the stratospheric heat budget 2 . Global radiation balance and diabatic circulations, J. Geophys. Res., 104(D6), 6039-6066, 1999.

Natarajan, M. and Callis, L. B.: Stratospheric photochemical studies with Atmospheric Trace Molecule Spectroscopy (ATMOS) measurements, J. Geophys. Res., 96, 9361-9370, 1991.

Natarajan, M., Callis, L. B., Boughner, R. E., Russell III, J. M., and Lambeth, J. D.: Stratospheric photochemical studies using Nimbus 7 data. 1. Ozone photochemistry, J. Geophys. Res., 91, 1153-1166, 1986.

Natarajan, M., Remsberg, E. E., and Gordley, L. L.: Ozone budget in the upper stratosphere: Model studies using the reprocessed LIMS and the HALOE datasets, Geophys. Res. Lett., 29, 56-61, 2002.

Natarajan, M., Remsberg, E. E., Deaver, L. E., and Russell III, J. M.: Anomalously high levels of $\mathrm{NO}_{\mathrm{x}}$ in the polar upper stratosphere during April, 2004; Photochemical consistency of HALOE observations, Geophys. Res. Lett., 31, L15113, doi:10.1029/2004GL020566, 2004.

Noxon, J. F.: Stratospheric $\mathrm{NO}_{2}$. 2. Global behavior, J. Geophys. Res., 84, 5067-5076, 1979.

Perrin, A., Camy-Peyret, C., and Flaud, J.-M.: Infrared nitrogen dioxide: line parameters in the HITRAN database, J. Quant. Spectrosc. Radiat. Transfer, 48, 645-651, 1992.

Randall, C. E., Harvey, V. L., Singleton, C. S., Bernath, P. F., Boone, C. D., and Kozyra, J. U.: Enhanced $\mathrm{NO}_{\mathrm{x}}$ in 2006 linked to strong upper stratospheric Arctic vortex, Geophys. Res. Lett., 33, L18811, doi:10.1029/2006GL027160, 2006.

Randall, C. E., Harvey, V. L., Singleton, C. S., Bailey, S. M., Bernath, P. F., Cordrescu, M., Nakajima, H., and Russell III, J. M.: Energetic particle precipitation effects on the Southern Hemisphere stratosphere in 1992-2005, J. Geophys. Res., 112, D08308, doi:10.1029/2006JD007696, 2007.

Randall, C. E., Harvey, V. L., Siskind, D. E., France, J., Bernath, P. F., Boone, C. D., and Walker, K. A.: $\mathrm{NO}_{\mathrm{x}}$ descent in the Arctic middle atmosphere in early 2009 , Geophys. Res. Lett., 36, L18811, doi:10.1029/2009GL039706, 2009.

Remsberg, E. E. and Bhatt, P. P.: Zonal variances of nitric acid vapor as an indicator of meridional mixing in the subtropical lower stratosphere, J. Geophys. Res., 101(D23), 29523-29530, 1996.

Remsberg, E. E., and Lingenfelser, G.: LIMS version 6 level 3 dataset, NASA Technical Memorandum 2010-216690, available at http://www.sti.nasa.gov, 13 pp., 2010.

Remsberg, E. E. and Russell III, J. M.: The near global distributions of middle atmospheric $\mathrm{H}_{2} \mathrm{O}$ and $\mathrm{NO}_{2}$ measured by the Nimbus 7 LIMS experiment, in Transport Processes in the Middle Atmosphere, edited by: Visconti, G. and Garcia, R., D. Reidel Publ. Co., Dordrecht, Holland, 87-102, 1987.

Remsberg, E. E., Natarajan, M., Lingenfelser, G. S., Thompson, R. E., Marshall, B. T., and Gordley, L. L.: On the quality of the Nimbus 7 LIMS Version 6 water vapor profiles and distributions, Atmos. Chem. Phys., 9, 9155-9167, doi:10.5194/acp-9-9155-2009, 2009.

Remsberg, E., Lingenfelser, G., Natarajan, M., Gordley, L., Marshall, B. T., and Thompson, E.: On the quality of the Nimbus 7 LIMS version 6 ozone for studies of the middle atmosphere, J. Quant. Spectrosc. Rad. Transf., 105, 492-518, doi:10.1016/j.jqsrt.2006.12.005, 2007.
Remsberg, E. E., Gordley, L. L., Marshall, B. T., Thompson, R. E., Burton, J., Bhatt, P., Harvey, V. L., Lingenfelser, G. S., and Natarajan, M.: The Nimbus 7 LIMS Version 6 radiance conditioning and temperature retrieval methods and results, J. Quant. Spectrosc. Rad. Transf., 86, 395-424, doi:10.1016/j.jqsrt.2003.12.007, 2004.

Remsberg, E. E., Bhatt, P. P., Eckman, R. S., Gordley, L. L., Russell III, J. M., and Siskind, D. E.: Effect of the HITRAN 92 spectral data on the retrieval of $\mathrm{NO}_{2}$ mixing ratios from Nimbus 7 LIMS, J. Geophys. Res., 99, 22965-22973, 1994.

Rothman, L. S., Gamache, R. R., Tipping, R. H., Rinsland, C. P., Smith, M. A. H., Benner, D. C., Devi, V. M., Flaud, J.-M., CamyPeyret, C., Perrin, A., Goldman, A., Massie, S. T., Brown, L. R., and Toth, R. A.: The HITRAN molecular database: editions of 1991 and 1992, J. Quant. Spectrosc. Radiat. Transfer, 48, 469507, 1992a.

Rothman, L. S., Hawkins, R. S., Wattson, R. B., and Gamache, R. R.: Energy levels, intensities, and linewidths of atmospheric carbon dioxide bands, J. Quant. Spectrosc. Radiat. Transfer, 48, 537-566, 1992b.

Rothman, L. S., Goldman, A., Gillis, J. R., Tipping, R. H., Brown, L. R., Margolis, J. S., Maki, A. G., and Young, L. D. G.: AFGL trace gas compilation: 1980 edition, Appl. Opt., 20, 1323-1328, 1981.

Rothman, L. S., Rinsland, C. P., Goldman, A., Massie, S. T., Edwards, D. P., Flaud, J.-M., Perrin, A., Camy-Peyret, C., Dana, V., Mandin, J.-Y., Schroeder, J., McCann, A., Gamache, R. R., Wattson, R. B., Yoshino, K., Chance, K. V., Jucks, K. W., Brown, L. R., Nemtchinov., V., and Varanasi, P.: The HITRAN molecular spectroscopic database and HAWKS (HITRAN atmospheric workstation): 1996 edition, J. Quant. Spectrosc. Radiat. Transfer, 60, 665-710, 1998.

Russell III, J. M. and Gille, J. C.: The limb infrared monitor of the stratosphere (LIMS) experiment, in The NIMBUS 7 Users' Guide, edited by: Madrid, C. R., 71-103, NASA Goddard Space Flight Center, Greenbelt, MD., 1978.

Russell III, J. R., Gille, J. C., Remsberg, E. E., Gordley, L. L., Bailey, P. L., Drayson, S. R., Fischer, H., Girard, A., Harries, J. E., and Evans, W. F. J.: Validation of nitrogen dioxide results measured by the limb infrared monitor of the stratosphere (LIMS) experiment on NIMBUS 7, J. Geophys. Res., 89, 5099-5107, 1984a.

Russell III, J. M., Solomon, S., Gordley, L. L., Remsberg, E. E., and Callis, L. B.: The variability of stratospheric and mesospheric $\mathrm{NO}_{2}$ in the polar winter night observed by LIMS, J. Geophys. Res., 89, 7267-7275, 1984b.

Sander, S. P., Friedl, R. R., Ravishankara, A. R., Golden, D. M., Kolb, C. E., Kurylo, M. J., Molina, M. J., Moortgat, G. K., Keller-Rudek, H., Finlayson-Pitts, B. J., Wine, P. A., Huie, R. E., and Orkin, V. L.: Chemical kinetics and photochemical data for use in atmospheric studies - Evaluation Number 15, JPL Publication 06-2, Jet Propulsion Laboratory, Pasadena, CA, 2006.

Santee, M. L., Lambert, A., Read, W. G., Livesey, N. J., Cofield, R. E., Cuddy, D. T., Daffer, W. H., Frouin, B. J., Froidevaux, L., Fuller, R. A., Jarnot, R. F., Knosp, B. W., Manney, G. L., Perun, V. S., Snyder, W. V., Stek, P. C., Thurstans, R. P., Wagner, P. A., Waters, J. W., Muscari, G., DeZafra, R. L., Dibb, J. E., Fahey, D. W., Popp, P. J., Marcy, T. P., Jucks, K. W., Toon, G. C., Stachnik, R. A., Bernath, P. F., Boone, C. D., Walker, K. A., Urban, 
J., and Murtagh, D.: Validation of the Aura Microwave Limb Sounder $\mathrm{HNO}_{3}$ measurements, J. Geophys. Res., 112, D24S40, doi:10.1029/2007JD008721, 2007.

Solomon, S., Russell III, J. M., and Gordley, L. L.: Observations of the diurnal variation of nitrogen dioxide in the stratosphere, $\mathrm{J}$. Geophys. Res., 91, 5455-5464, 1986.

Stiller, G. P., Mengistu Tsidu, G., von Clarmann, T., Glatthor, N., Höpfner, M., Kellmann, S., Linden, A., Ruhnke, R., Fischer, H., Lopez-Puertas, M., Funke, B., and Gil-Lopez, S.: An enhanced $\mathrm{HNO}_{3}$ second maximum in the Antarctic midwinter upper stratosphere 2003, J. Geophys. Res., 110, D20303, doi:10.1029/2005JD006011, 2005.

Thibault, F., Menoux, V., LeDoucen, R., Rosenmann, L., Hartmann, J.-M., and Boulet, C.: Infrared collision-induced absorption by $\mathrm{O}_{2}$ near $6.4 \mu \mathrm{m}$ for atmospheric applications: measurements and empirical modeling, Appl. Opt., 36, 563-567, 1997.
Thomason, L. W., Poole, L. R., and Deshler, T.: A global climatology of stratospheric aerosol surface area density deduced from Stratospheric Aerosol and Gas Experiment II measurements: 1984-1994, J. Geophys. Res., 102, 8967-8976, 1997.

Toth, R. A.: High-resolution measurements and analysis of ${ }^{14} \mathrm{~N}^{16} \mathrm{O}_{2}$ in the [001]-[000] and [011]-[010] bands, J. Opt. Soc. Am. B, 9, 433-461, 1992.

Wetzel, G., Bracher, A., Funke, B., Goutail, F., Hendrick, F., Lambert, J.-C., Mikuteit, S., Piccolo, C., Pirre, M., Bazureau, A., Belotti, C., Blumenstock, T., De Mazière, M., Fischer, H., Huret, N., Ionov, D., López-Puertas, M., Maucher, G., Oelhaf, H., Pommereau, J.-P., Ruhnke, R., Sinnhuber, M., Stiller, G., Van Roozendael, M., and Zhang, G.: Validation of MIPASENVISAT NO2 operational data, Atmos. Chem. Phys., 7, 32613284, doi:10.5194/acp-7-3261-2007, 2007. 